\title{
HIBRIDAÇÃO SOMÁTICA ENTRE LARANJA 'CAIPIRA' E LIMÃO 'CRAVO’ ATRAVÉS DE FUSÃO DE PROTOPLASTOS
}

\author{
FERNANDA JANUZZI MENDES DA GLORIA
}

Engenheira Agrônoma

Orientador: Prof. Dr. FRANCISCO DE ASSIS ALVES MOURÃO FILHO

Dissertação apresentada à Escola Superior de
Agricultura "Luiz de Queiroz", Universidade de São
Paulo, para obtenção do título de Mestre em
Agronomia, Área de Concentração: Fitotecnia.

PIRACICABA

Estado de São Paulo - Brasil

Setembro - 1998 


\section{ERRATA}

\begin{tabular}{|l|l|l|l|}
\hline Pág. & Linha & \multicolumn{1}{|c|}{ Onde se lê } & \multicolumn{1}{|c|}{ Leia-se } \\
\hline viii & 14 & os & as \\
\hline 11 & 19 & Jr. & Junior \\
\hline 11 & 29 & Jr. & Junior \\
\hline 12 & 1 & Jr. & Junior \\
\hline 12 & 18 & Jr. & Junior \\
\hline 13 & 8 & Jr. & Junior \\
\hline 38 & 2 & de & - \\
\hline 47 & 9 & de & - \\
\hline 51 & 11 & $\mathrm{BH}_{3}$ & $\begin{array}{l}\mathrm{BH}_{3} \quad \text { Grosser \& Gmitter Junior, } \\
1990 \mathrm{a})\end{array}$ \\
\hline 54 & 7 & repetodas & repetidas \\
\hline 54 & 13 & $10 \mu$ brometo : $100 \mathrm{ml}$ gel & $5 \mu \mathrm{g}$ brometo/ml gel \\
\hline
\end{tabular}

Pág. 33 - Figura 2

\section{Onde se lê:}

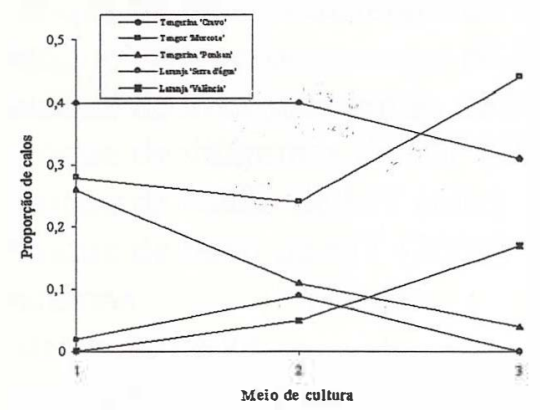

\section{Leia-se:}
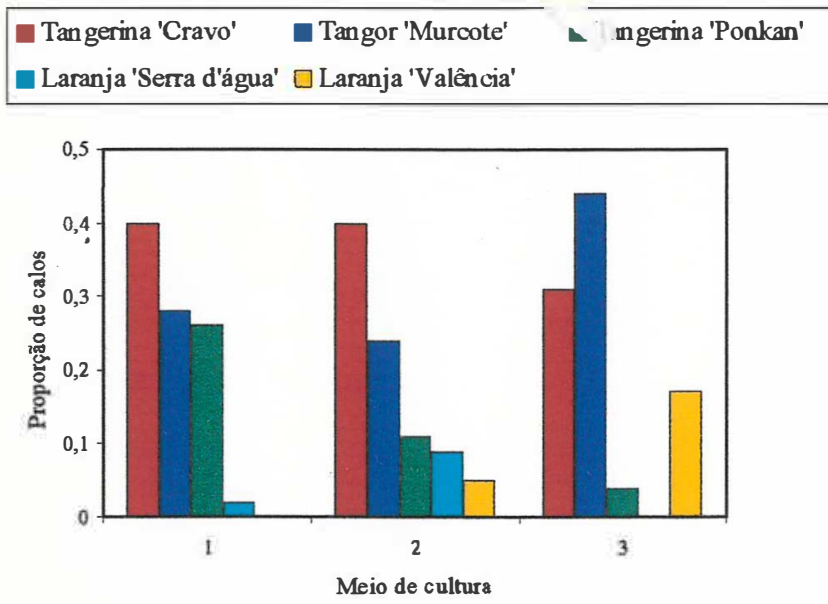
Dados Internacionais de Catalogação na Publicação (CIP)

DIVISÃO DE BIBLIOTECA E DOCUMENTAÇÃO - Campus "Luiz de Oueiroz"/USP

Mendes-da-Gloria, Fernanda Januzzi

Hibridação somática entre laranja 'Caipira' e limão 'Cravo' atravès de fusāo de protoplastos / Fernanda Januzzi Mendes-da-Gloria. - Piracicaba, 1998.

$78 \mathrm{p}$.

Dissertação (mestrado) - - Escola Superior de Agricultura Luiz de Queiroz, 1998. Bibliografia.

1. Biotecnologia vegetal 2. Cultura de tecido vegetal 3. Embriogênese somática 4. Fusão de protoplasto 5. Melhoramento genético vegetal 6. Porta enxerto 7.

Variedade I. Título 
Dedico este trabalho aos meus pais, que muito fizeram para minha formação e ao meu marido pelo constante apoio. 


\section{Agradecimentos}

Gostaria de agradecer às pessoas e instituições que contribuiram para desenvolvimento deste trabalho:

Ao Prof. Dr. Francisco de Assis Alves Mourão Filho, pela orientação, constante disponibilidade e amizade.

À Prof. Dra. Beatriz M. Januzzi Mendes, do Laboratório de Biotecnologia Vegetal do CENA, pelo apoio, contribuição na orientação e por ter cedido as instalações do laboratório, nas quais foram realizadas grande parte do trabalho prático.

À Escola Superior de Agricultura "Luiz de Queiroz" e ao Departamento de Horticultura, pela oportunidade de realização do curso.

À FAPESP, pela bolsa de estudos, auxílio em participação de reuniões científicas e financiamento do projeto.

Ao Prof. Dr. Luis Eduardo Aranha Camargo, do Departamento de Fitopatologia, pelo auxílio na realização das análises moleculares.

À Prof. Dra. Maria Lucia Vieira Carneiro do Departamento de Genética, pelo auxílio no desenvolvimento de análises citológicas e atenção do técnico Carlos Alberto de Oliveira na realização das análises.

À Prof. Dra. Adriana Pinheiro Martineli Rodriguez, do Laboratório de Biotecnologia Vegetal do CENA, pelo auxílio no desenvolvimento do trabalho e constante disponibilidade.

À Prof. Dra. Clarice Borges Demetrio, do Departamento de Matemática e Estatística, pelo auxílio nas análises estatísticas.

Ao Laboratório de Propagação de Plantas, do Departamento de Horticultura, onde foi desenvolvida a parte final do trabalho.

Ao Centro de Citricultura "Sylvio Moreira", pela atenção e fornecimento de frutos utilizados no trabalho.

À Biblioteca Central da ESALQ; aos funcionários do Departamento de Horticultura. 
Às colegas Adriana Patricia Ricci e Hérika Aparecida Bequis Araujo Zaia, pelo auxílio no desenvolvimento da parte prática, aos colegas do curso de Pós-graduação em Fitotecnia da ESALQ e do Laboratório de Biotecnologia Vegetal do CENA, pelo apoio e amizade. 


\section{SUMÁRIO}

Página

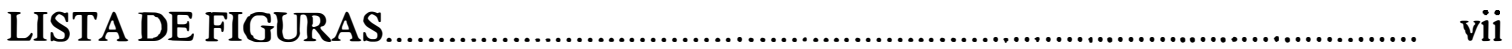

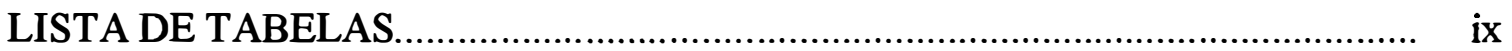

RESUMO

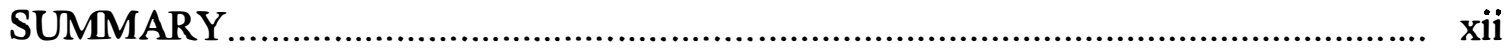

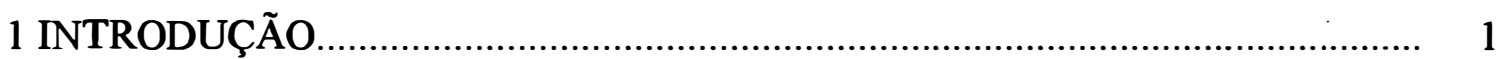

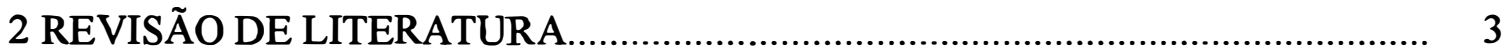

2.1 Importancia da utilização de porta-enxertos na citricultura...................................... 3

2.2 Melhoramento de porta-enxertos de citros..................................................... 11

2.3 Utilização da biotecnologia no melhoramento de citros....................................... 14

2.3.1 Hibridação somática............................................................................... 15

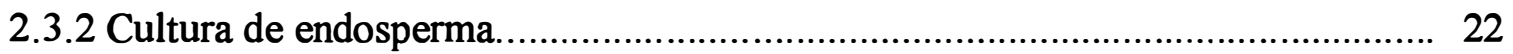

2.3.3 Transformação genética........................................................................ 22

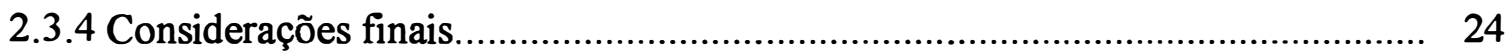

3 INDUÇÃO DE CALOS EMBRIOGÊNICOS EM TECIDO NUCELAR DE SETE CULTIVARES DE CITROS................................................................... 26

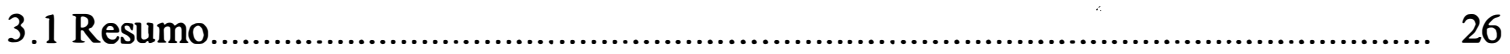

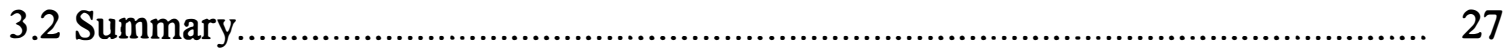

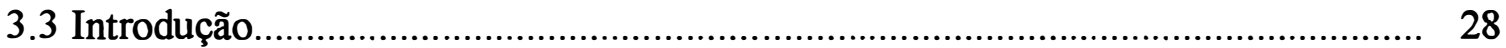

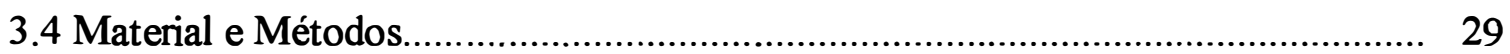

3.5 Resultados e Discussão....................................................................... 30

3.6 Conclusões......................................................................................... 35

4 EFEITO DE DIFERENTES FONTES DE CARBONO NO ESTÍMULO

À EMBRIOGÊNESE SOMÁTICA DE CALOS OBTIDOS DE FUSÃO DE PROTOPLASTOS DE CITROS .......................................................... 36

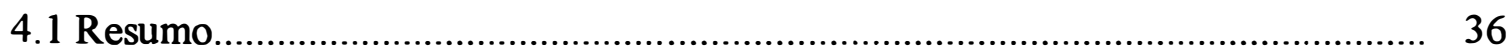

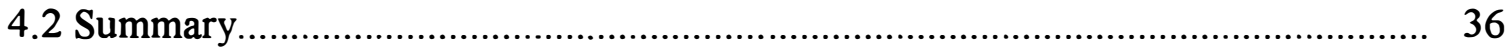

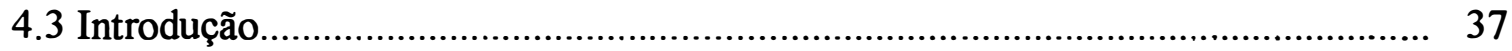

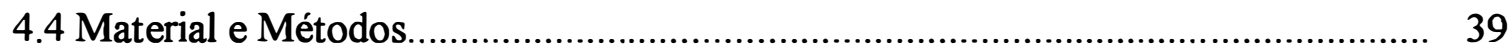




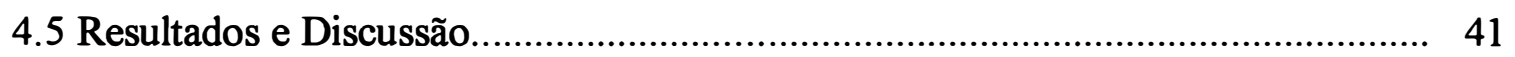

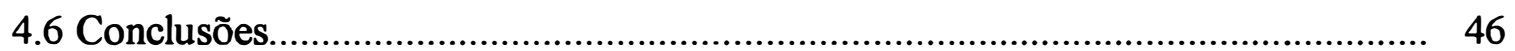

5 HIBRIDAÇÃO SOMÁTICA ENTRE LARANJA 'CAIPIRA' E LIMÃO 'CRAVO'ATRAVÉSDEFUSÃODEPROTOPLASTOS....................................... 47

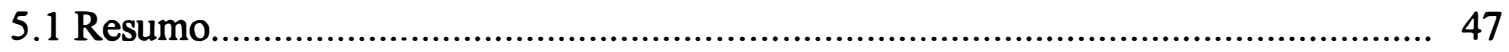

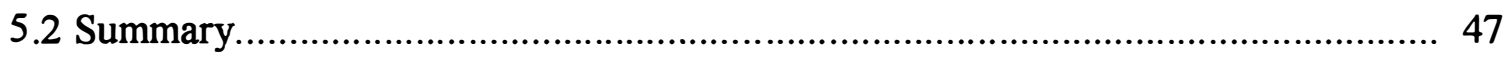

5.3 Introdução

5.4 Material e Métodos............................................................................... 50

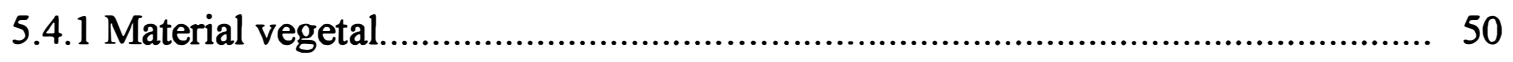

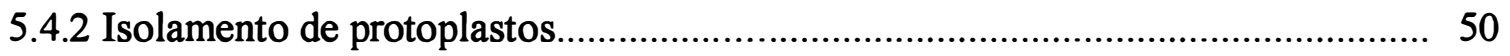

5.4.3 Purificação, fusão e plaqueamento dos protoplastos........................................... 51

5.4.4 Cultura dos protoplastos, indução à embriogênese e regeneração de plantas...... 51

5.4.5 Aclimatização....................................................................................... 52

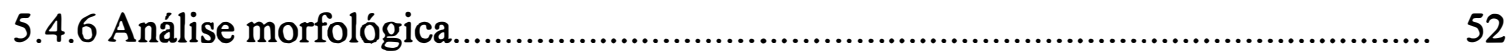

5.4.7 Contagem do número de cromossomos.................................................... 52

5.4.8 Análise de DNA através de marcadores moleculares tipo RAPD....................... 53

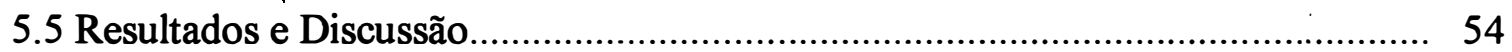

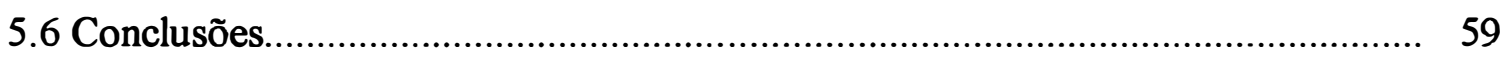

6 CONCLUSÕES

ANEXO

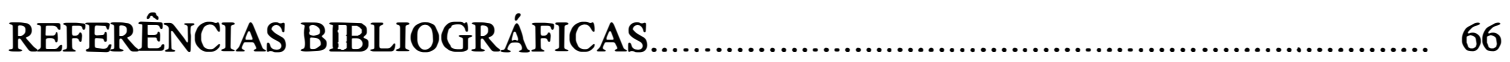




\section{LISTA DE FIGURAS}

Página

1 Tipos de calos obtidos no experimento de indução de calos embriogênicos

2 Proporção de resposta de tecido nucelar à indução de calos friáveis (de crescimento lento e rápido) de cinco cultivares de citros em três meios de cultura diferentes, após 120 dias de cultivo. Meio de cultura $1=\mathrm{EME}$; meio de cultura $2=$ 1/2-EME; meio de cultura $3=$ EBA

3 Embriões em fase de germinação das combinações laranja 'Caipira' + limão 'Rugoso da Flórida' (A), laranja 'Caipira' + tangerina 'Cleópatra' (B) e laranja 'Pera' + tangerina 'Cleópatra' (C)

4 Sequência das fases de isolamento de protoplastos até a planta aclimatizada.

5 Morfologia foliar de laranja 'Caipira' (esquerda), laranja

'Caipira' + limão ‘Cravo' (centro) e limão ‘Cravo' (direita). 
6 Célula da plântula obtida de fusão de protoplastos contendo 36 cromossomos................................................................................ 57

7 Padrões de RAPD do híbrido somático e de seus parentais.................................. 58 


\section{LISTA DE TABELAS}

Página

1 Características dos principais porta-enxertos de citros................................. 10

2 Análise de "deviance" para dados de indução de calos embriogênicos de sete cultivares diferentes de citros em três meios de cultura diferentes

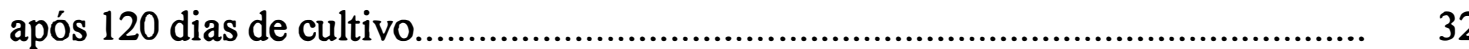

3 Rendimento de protoplastos de culturas de calos embriogênicos de cinco cultivares selecionados

4 Combinações parentais selecionadas para experimentos de fusão de protoplastos.

5 Número médio de embriões obtidos por combinação de calos de fusão de protoplastops em cada meio de cultura após 60 dias de cultivo \pm desvio padrão de seis repetições.. 


\title{
HIBRIDAÇÃO SOMÁTICA ENTRE LARANJA 'CAIPIRA' E LIMÃO 'CRAVO’ ATRAVÉS DE FUSÃO DE PROTOPLASTOS
}

\author{
Autora: Fernanda Januzzi Mendes da Gloria
}

Orientador: Prof. Dr. Francisco de Assis Alves Mourão Filho

\section{RESUMO}

Este trabalho teve como objetivo produzir híbrido somático de citros via fusão de protoplastos, a ser utilizado como porta-enxerto de citros. Experimentos preliminares envolveram a indução de calos embriogênicos de sete cultivares de citros a serem utilizados em experimentos de isolamento e fusão de protoplastos de citros. Os cultivares introduzidos foram: tangerinas 'Cravo' e 'Ponkan' (Citrus reticulata Blanco), tangor 'Murcote' (Citrus reticulata Blanco x Citrus sinensis L. Osbeck) e laranjas 'Serra d'água', 'Natal', 'Valência' e 'Pera' (Citrus sinensis L. Osbeck). Foram introduzidos 50 nucelos de cada cultivar em três meios de cultura diferentes (EME, 1/2EME e EBA). Calos embriogênicos foram obtidos em todas os cultivares, exceto em laranja 'Pera', que produziu somente calos duros. Paralelamente ao experimento acima, foi desenvolvido um outro experimento para avaliar o efeito de diferentes fontes de carbono na indução da embriogênese somática de calos obtidos de fusão de protoplastos de laranja 'Caipira' (Citrus sinensis L. Osbeck) + tangerina 'Cleópatra' (Citrus reshni Hort. ex Tanaka), laranja 'Caipira' (C. sinensis) + limão 'Rugoso da Flórida' (Citrus jambhiri 
Lushington), laranja 'Pera' (Citrus sinensis L. Osbeck) + tangerina 'Cleópatra' ( $C$. reshni) e limão 'Cravo' (Citrus limonia L. Osbeck) + laranja 'Azeda' (Citrus aurantium L.). O meio de cultura básico utilizado foi $\mathrm{MT}+$ extrato de malte $\left(500 \mathrm{mg} \mathrm{l}^{-1}\right)$, adicionado de sacarose $(0,145 \mathrm{M})$, lactose $(0,145 \mathrm{M})$, maltose $(0,145 \mathrm{M})$ ou galactose + sorbitol $(0,1 \mathrm{M}+0,1 \mathrm{M})$. $\mathrm{O}$ açúcar que melhor estimulou a embriogênese somática foi a maltose, seguido pela lactose, galactose + sorbitol e sacarose respectivamente, exceto na combinação laranja 'Caipira' + tangerina 'Cleópatra', onde a combinação galactose + sorbitol foi o segundo melhor açúcar em vez de lactose. Finalmente, foram realizados experimentos de fusão de protoplastos de laranja 'Caipira' (C. sinensis) + limão 'Cravo' (C. limonia) por via química, utilizando-se solução de polietilenoglicol (PEG). $\mathrm{O}$ cultivo dos protoplastos foi feito em meio líquido. Microcalos foram transferidos para EME semi-sólido e a embriogênese somática foi observada após 60 dias de cultivo. A regeneração de plantas se deu em meio de cultura EME $+\mathrm{GA}_{3}$. A confirmação da hibridação somática de 4 das 39 plantas regeneradas foi feita por meio de análise da morfologia foliar, contagem do número de cromossomos e de análise molecular (RAPD). 


\title{
SOMATIC HYBRIDIZATION OF 'CAIPIRA' SWEET ORANGE AND 'RANGPUR' LIME VIA PROTOPLAST FUSION
}

\author{
Author: Fernanda Januzzi Mendes da Gloria
}

Adviser: Prof. Dr. Francisco de Assis Alves Mourão Filho

\section{SUMMARY}

The objective of this research was to produce citrus somatic hybrid via protoplast fusion be used as a citrus rootstock. Preliminary experiments involved calli induction of seven citrus cultivars to be used on protoplast isolation and fusion experiments. The cultivars were: 'Cravo' and 'Ponkan' mandarins (Citrus reticulata Blanco), 'Murcott' tangor (Citrus reticulata Blanco x Citrus sinensis. L. Osbeck), 'Serra d'água', 'Natal', 'Valência' and 'Pera' sweet oranges (Citrus sinensis L. Osbeck). Fifity nucelli of each cultivar were introduced onto three different culture media (EME, 1/2-EME and EBA). Embryogenic calli were obtained in all cultivars, except on 'Pera' sweet orange, that produced only hard calli. Paralel with the above experiment, it was developed another experiment to evaluate different carbon sources on somatic induction of embryogenesis in calli of 'Caipira' sweet orange $(C$. sinensis) + 'Cleopatra' mandarin (Citrus reshni Hort. ex Tanaka), 'Caipira' sweet orange (C. sinensis) + 'Florida Rough' lemon (Citrus jambhiri Lushington), 'Pera' sweet orange (Citrus sinensis L. Osbeck) + 'Cleopatra' mandarin (C. reshni), 'Rangpur' lime (C. limonia) + 'Sour' orange (Citrus aurantium L.) fusions. The basic culture media was MT + malt extract $\left(500 \mathrm{mg} \mathrm{l}^{-1}\right)$ with sucrose 
$(0.145 \mathrm{M})$, lactose $(0.145 \mathrm{M})$, maltose $(0.145 \mathrm{M})$ or galactose $(0.1 \mathrm{M})+$ sorbitol $(0.1 \mathrm{M})$. The sugar that best estimulated somatic embryogenesis was maltose, followed by lactose, galactose + sorbitol and sucrose, except on 'Caipira' sweet orange + 'Cleopatra' mandarin combination, where galactose + sorbitol was the second best sugar rather than lactose. Protoplast fusion experiment of 'Caipira' sweet orange (Citrus sinensis L. Osbeck) + 'Rangpur' lime (Citrus limonia L. Osbeck) were induced by chemical method, with poliethylene glycol (PEG) solution. Protoplasts were cultured on liquid medium. Microcalli were transfered to semi-solid EME medium. Somatic embryogenesis was observed 60 days after culture. Somatic embryos were germinatated on $\mathrm{EME}+0,5 \mathrm{mg} \mathrm{l}^{-1} \mathrm{GA}_{3}$. Four, out of 39 regenerated plants were confirmed as somatic hybrids by leaf morfological evaluation, chromossome counting and RAPD analyses. 


\section{INTRODUÇÃO}

Dentre as frutas cítricas, as laranjas são as produzidas em maior quantidade no mundo. O Brasil ocupa a primeira posição na produção mundial de laranjas, sendo também o maior produtor de suco concentrado do mundo. No Brasil, o principal produtor de frutas cítricas é o Estado de São Paulo.

Embora seja o maior produtor do mundo, a produtividade de citros no Brasil tem sido muito afetada por problemas de pragas e doenças. Esses fatos têm limitado a produção de frutos de qualidade e o aumento da produtividade.

A obtenção de variedades melhoradas quanto a tolerância a problemas fitossanitários auxiliaria no desenvolvimento da citricultura. Entretanto, existe uma grande dificuldade na obtenção de variedades melhoradas devido a aspectos da biologia reprodutiva do gênero Citrus. Desta forma, a maioria das variedades econōmicamente importantes foram obtidas de seleção de variedades já existentes e não de programas de melhoramento.

Utilizando-se diferentes técnicas biotecnologicas, tem-se conseguido ultrapassar barreiras naturais ao melhoramento dos citros, contribuindo desse modo com programas de melhoramento convencional e auxiliando no desenvolvimento de variedades melhoradas.

Com o objetivo de auxiliar no desenvolvimento de variedades melhoradas de citros, esse trabalho teve como objetivo a obtenção de calos embriogênicos de variedades de interesse econômico que pudessem ser utilizados posteriormente em trabalhos biotecnológicos voltados para o melhoramento de citros; contribuir para a adaptação de protocolos de fusão química de protoplastos e regeneração de plantas para 
variedades brasileiras, visando a produção de híbridos somáticos, a serem utilizados como porta-enxertos. 


\section{REVISÃO DE LITERATURA}

\subsection{Importância da utilização de porta-enxertos na citricultura.}

Durante muito tempo, as plantas cítricas foram propagadas por sementes. Devido a esse fato, apresentavam longo período juvenil, eram excessivamente vigorosas, com crescimento vertical e apresentavam ramos espinhosos. $\mathrm{O}$ tempo para o retorno do investimento era muito maior devido a entrada tardia das plantas em produção. Além das desvantagens mencionadas acima, a maioria das plantas cítricas obtidas de sementes apresenta susceptibilidade à problemas de solo, como a gomose, causada por fungos do gênero Phytophthora e nematóides (Davies \& Albrigo, 1994).

Com o aparecimento da gomose, primeiro na Ilha dos Açores em 1842 e mais tarde em quase todos os países produtores de citros, as mudas cítricas deixaram de ser obtidas a partir de sementes, sendo necessário utilizar-se de copas enxertadas em portaenxertos tolerantes à essa doença (Chapot, 1975).

Mais de 20 características da planta são influenciadas pelo porta-enxerto (Castle, 1987). O porta-enxerto induz diversas alterações na copa, como crescimento, porte, precocidade de produção, produtividade, época de maturação, peso dos frutos, coloração da casca e do suco, teor de ácidos e açúcares dos frutos, permanência dos frutos na planta, conservação do fruto após a colheita, transpiração das folhas, fertilidade do pólen, composição química das folhas, capacidade de absorção, tolerância à salinidade, resistência à seca e ao frio, resistência e tolerância a moléstias e pragas. Características do porta-enxerto também são influenciadas pela copa, sendo as mais evidentes quanto ao desenvolvimento do sistema radicular, resistência ao frio, à seca e a moléstias (Pompeu Junior, 1991). * 
No Brasil, a utilização de plantas enxertadas se deu apenas no início deste século, quando a citricultura brasileira alcançou expressão comercial, tendo como principal porta-enxerto utilizado, a laranja 'Caipira' (Citrus sinensis L. Osbeck) (Pompeu Junior, 1991). Entretanto, a laranja 'Caipira' é pouco resistente à gomose e à seca, o que fez com que fosse substituída pela laranja 'Azeda' (Citrus aurantium L.), que estava se tornando o porta-enxerto mais utilizado no mundo.

A grande preferência brasileira pelo porta-enxerto laranja 'Azeda', de acordo com Moreira (1941) se dava devido às condições favoráveis ao desenvolvimento desse cavalo, boa afinidade com a maioria das variedades comerciais, além da qualidade das frutas produzidas sobre esse porta-enxerto.

No Brasil, durante quase duas décadas (1920 - 1940), a laranja 'Azeda' foi o principal porta-enxerto utilizado, até o aparecimento do vírus da Tristeza no Vale do Paraíba, em 1937. Devido à grande disseminação da virose pelo pulgão preto (Toxoptera citricidus), boa parte da citricultura brasileira foi destruída (Pompeu Junior, 1991).

O porta-enxerto laranja 'Azeda' foi muito afetado quando enxertado com laranjas doces, tangerinas e pomelos, exceto por limões verdadeiros. Desse modo, a laranja 'Azeda' foi substituída por outros porta-enxertos como limão 'Rugoso' (Citrus jambhiri Lushington), limão 'Cravo' (Citrus limonia L. Osbeck), tangerina 'Cleópatra' (Citrus reshni Hort. ex Tanaka) e citrange 'Troyer' (Citrus sinensis L. Osbeck $\mathrm{x}$ Poncirus trifoliata Rafinesque) (Chapot, 1975).

A partir dos anos 60 , a citricultura brasileira foi novamente instalada, praticamente em um só porta-enxerto, o limão 'Cravo' (C. limonia L. Osbeck), que é tolerante ao vírus da tristeza e à seca (Pompeu Junior, 1991).

A partir da década de 70, surge o declínio dos citros (Pompeu Junior, 1991), uma doença de causa desconhecida, que se torna problema maior em regiões citrícolas úmidas como Flórida e Brasil, tendo como porta-enxertos mais susceptíveis Poncirus trifoliata, limão ‘Rugoso' (C. jambhiri) e limão 'Cravo' (C. limonia) (Grosser \& Gmitter Junior, 1990a). O declínio vem causando a morte de milhões de plantas enxertadas sobre esse cavalo. 
A história da citricultura vem mostrando a importância da diversificação na utilização de porta-enxertos, além da necessidade de variedades porta-enxerto melhoradas. A utilização generalizada de um único porta-enxerto para todas as variedades copa provavelmente nã̉o atende às características peculiares de cada cultivar, impedindo que a planta, mesmo recebendo os tratos culturais adequados, manifeste todo o seu potencial produtivo (Pompeu Junior et al., 1986).

Com o objetivo de diversificar a utilização de porta-exertos para variedades copa de grande importância econômica, aumento da produtividade, melhoria da qualidade dos frutos e maior segurança fitossanitária, diversos experimentos vem sendo desenvolvidos. Esta revisão procurará reunir os trabalhos relevantes já realizados no Brasil.

Vasconcellos (1939) realizou um dos trabalhos pioneiros nesta área, avaliando o comportamento de laranja 'Bahia Comum' (Citrus sinensis L. Osbeck) sobre cinco diferentes porta-enxertos: lima 'da Pérsia' (Citrus limettioides, Tanaka), laranja 'Azeda' (C. aurantium), laranja 'Serra d'água' (Citrus sinensis L. Osbeck), limão 'Cravo' ( $C$. limonia) e limão 'Rugoso’ (C. jambhiri). Avaliou-se o vigor, produção e qualidade dos frutos, e o autor verificou a superioridade da laranja 'Azeda' e da lima 'da Pérsia' como porta-enxertos para laranja 'Bahia Comum'. Naquela época, a doença tristeza não havia sido constatada em Piracicaba, local da realização ensaio.

Moreira (1941) relata a avaliação de um experimento onde avaliou-se o comportamento de doze cavalos com as principais variedades comerciais da época ['Baianinha', 'Pera' ( Citrus sinensis L. Osbeck) e pomelo 'Marsh seedless' (Citrus paradisi Macfadyen)]. Avaliações feitas no viveiro revelaram um comportamento diferencial das variedades porta-enxerto em relação ao vigor, sendo que as variedades lima 'da Pérsia' (Citrus limettioides, Tanaka), limão 'Cravo' (C. limonia), limão 'Rugoso' (C. jambhiri) e 'cidra' (Citrus medica L.) foram as que apresentaram crescimento mais rápido e mudas maiores. Brieger \& Moreira (1945) e Moreira (1946) relataram os resultados de produção do ensaio anterior após sua instalação e recomendaram os porta-enxertos laranja 'Caipira' (C. sinensis), limão 'Rugoso Nacional' (C. jambhiri) e laranja 'Lima' (C. sinensis L. Osbeck) para as copas laranja 
'Baianinha' e pomelo 'Marsh-seedless'. Para laranja 'Pera', foi recomendado a lima 'da Pérsia', o limão 'Cravo' e as laranjas 'Lima' e 'Caipira' como porta-enxertos.

Moreira et al. (1965) apresentaram os resultados de experimento de seis variedades copa (limão 'Eureka', laranja 'Baianinha', 'Pera', 'Hamlin' e 'Maracanã' e a tangerina 'Mexirica') enxertadas em diferentes porta-enxertos. Para a copa laranja 'Pera' (C. sinensis), as maiores produções obtidas neste período foram sobre os porta-enxertos laranja 'Caipira' (C. sinensis), tangerina 'Cravo' (Citrus reticulata, Blanco) e laranja 'Pera' (C. sinensis L. Obeck); o 'trifoliata' (Poncirus trifoliata Rafinesque) e os limões 'Cravo' (C. limonia) e 'Rugoso' (C. jambhiri) ocuparam posição intermediária; a lima 'da Pérsia' (Citrus limettioides, Tanaka), ocupou o último lugar .

Teófilo Sobrinho et al. (1969a) avaliaram o desempenho das laranjas 'Valência' (Citrus sinensis L. Osbeck) e 'Natal' (Citrus sinensis L. Osbeck) sobre nove porta-enxertos: limão 'Cravo' (C. limonia L. Osbeck), citrange 'Troyer' (Citrus sinensis L. Osbeck x Poncirus trifoliata Rafinesque), limão 'Rugoso Nacional' (Citrus jambhiri Lushington), Poncirus trifoliata Rafinesque, tangerina 'Cravo' (Citrus reticulata Blanco), laranja 'Caipira' (C. sinensis L. Osbeck), limão 'Rugoso da Flórida' (Citrus jambhiri Lushington), tangerina 'Cleópatra' (C. reshini Hort.) e tangerina 'Sunki' (Citrus sunki Hort. ex Tanaka). Esse experimento foi conduzido na Estação Experimental de Limeira, do Instituto Agronômico de São Paulo (Cordeirópolis, SP). A laranja 'Valência' apresentou as maiores produções quando enxertada nos cavalos limão 'Cravo' e 'Rugoso nacional', tangerina 'Sunki', limão 'Rugoso da Flórida' e laranja 'Caipira'. Para laranjeira 'Natal', o limão 'Cravo', 'Rugoso da Flórida' e 'Nacional', tangerina 'Sunki' e trifoliata induziram maiores produções às suas copas.

Teófilo Sobrinho et al. (1969b) estudaram a influência de nove porta-enxertos na produção de tangerina 'Cravo' (C. reticulata) e tangerina 'Ponkan' (Citrus reticulata Blanco), que são as tangerinas de grande importância no Estado de São Paulo. O ensaio foi instalado na Estação Experimental de Limeira do Instituto Agronômico de São Paulo (Cordeirópolis, SP). Os porta-enxertos utilizados foram: limão 'Cravo' (C. limonia), citrange 'Troyer' (C. sinensis x Poncirus trifoliata), limão 'Rugoso Nacional' ( $C$. jambhiri), Poncirus trifoliata, tangerina 'Cravo' (C. reticulata), laranja 'Caipira' (C. 
sinensis), limão 'Rugoso da Flórida' (C. jambhiri), tangerina 'Cleópatra' (C. reshni) e tangerina 'Sunki' (C. sunki). A tangerina 'Cravo' apresentou as melhores produções nos porta-enxertos limão 'Cravo', limão 'Rugoso Nacional' e 'da Flórida', tangerina 'Sunki' e trifoliata. Para tangerina 'Ponkan', sobressairam-se os porta-enxertos limão 'Cravo' e 'Rugoso da Flórida', tangerina 'Sunki', citrange 'Troyer' e tangerina 'Cleópatra'.

Em experimento de Figueiredo et al. (1973), avaliou-se o desempenho de dez porta-enxertos para a variedade tangerina 'Ponkan' (C. reticulata). O ensaio foi conduzido na Estação Experimental de Tietê, SP. Os cavalos utilizados no experimento foram: limão 'Cravo' ( $C$. limonia), limões 'Rugoso Nacional' e 'Rugoso da Flórida' $(C$. jambhiri), laranja 'Caipira' (C. sinensis), tangerina 'Cleópatra' (C. reshni), tangerina 'Sunki' (C. sunki), lima 'da Pérsia' (C. limettioides), citrange 'Troyer' (C. sinensis $\mathrm{x} P$. trifoliata), tangelo 'Orlando' (Citrus reticulata, Blanco x Citrus paradisi Macfadyen) e Poncirus trifoliata. Dentre os "cavalos" estudados, o citrange 'Troyer' e o trifoliata foram os mais indicados no caso de diversificação de porta-enxertos para tangerina 'Ponkan' nas condições estudadas e para as condições ecológicas do experimento são condenados os cavalos laranja 'Caipira' e lima 'da Pérsia'.

Figueiredo et al. (1986) avaliaram o desempenho de limão 'Siciliano' (Citrus limon L. Bur. F.) sobre 16 porta-enxertos. $\mathrm{O}$ experimento foi realizado em Ribeirão Preto, SP. Os cavalos testados foram: limões: 'Milam' (Citrus jambhiri Lushington), 'Cravo' (C. limonia), 'Rugoso da África' (Citrus jambhiri Lushington) e 'Rugoso Nacional' (C. jambhiri); tangerinas: 'Cleópatra' (C. reshni) e 'Sunki' (C. sunki); tangelos 'Seminole' e 'Orlando' (Citrus reticulata, Blanco $\mathrm{x}$ Citrus paradisi, Macfadyen); laranjas 'Caipira' (C. sinensis) e 'Azeda' "Doble Cálice" (C. aurantium L.); citranges 'Morton' e 'Carrizo' (Citrus sinensis L. Osbeck x Poncirus trifoliata Rafinesque) e limão 'Volkameriano' (Citrus volkameriana Palermo), Citrus karna e Citrus pennivesiculata. Avaliações de seis anos de produção mostraram que os portaenxertos citrange 'Morton', C. pennivesiculata, laranja 'Azeda' "Doble Cálice" e limão 'Cravo' foram em ordem decrescente os que apresentaram as maiores produções. De acordo com os dados do experimento, os cavalos citrange Morton, C. pennivesiculata e a 
laranja 'Azeda' "Doble Cálice" mostraram-se indicados para a diversificação na utilização de porta-enxertos para limão 'Siciliano'.

Pompeu Junior et al. (1986) avaliaram clones de limão 'Cravo' ('Limeira", "Phylipine", "Borneo", "Santa Barbara", "Japanshe", 'Rangpur 10.557" e "Egyptian") e de limão 'Volkamenriano' ("Australian", "Catania 1", "Catania 2" e "Palermo") como porta-enxertos para laranja 'Natal'. O experimento foi instalado em Casa Branca, SP em 1974. Dados coletados nos dez primeiros anos de experimento mostraram que os limões 'Cravo' "Santa Barbara", 'Phylipine", "Borneo" e 'Limeira" e o 'Volkameriano' "Catania 2" foram os mais produtivos e não se observou influência dos porta-enxertos na qualidade dos frutos. Entretanto, Pompeu Junior et al. (1981) verificaram que a produção das plantas sobre limão 'Volkameriano' diminui consideravelmente a partir do décimo ano de idade do pomar, sugerindo que esse porta-enxerto tenha vida útil curta.

Teófilo Sobrinho et al. (1986) avaliaram o comportamento dos porta-enxertos limão 'Cravo' (C. limonia), limão 'Volkameriano' (C. volkameriana), tangerina 'Sunki' (C. sunki), trifoliata 'Limeira" (Poncirus trifoliata Rafinesque), citranges 'Troyer' $\mathrm{e}$ 'Morton' (C. sinensis x P. trifoliata) e tangerina 'Cleópatra' (C. reshni) para laranja 'Pera' (C. sinensis), clone premunizado contra a Tristeza. $\mathrm{O}$ experimento foi realizado em Casa Branca, SP. Análise de seis anos de produção mostrou que os porta-enxertos tangerina 'Sunki', citrange 'Morton', tangerina 'Cleópatra' e limão 'Cravo' induziram as maiores produções, diferindo significativamente das produções proporcionadas pelos porta-enxertos citrange 'Troyer' e trifoliata. Com relação à qualidade dos frutos, não foi constatada diferença significativa entre os porta-enxertos. Sintomas visuais típicos de declínio foram constatados aos onze anos de idade e de maneira bastante severa em plantas de limão 'Cravo' e citrange 'Troyer'. O porta-enxerto tangerina 'Sunki' foi o único que não apresentou sintomas visuais da doença em nenhuma planta e o que mais se destacou nas condições do trabalho.

O grande interesse em estudar a laranja 'Pera' se dá por esta ser a variedade mais plantada no Estado de São Paulo e ser a preferida tanto para indústria quanto para mercado de fruta fresca. 
Teófilo Sobrinho et al. (1989) avaliaram o desempenho de sete porta-enxertos na produção e qualidade dos frutos de laranja 'Pera' (C. sinensis) clone premunizado, além de tolerância ao vírus da tristeza e ao declínio dos citros. Os resultados são referentes a dez anos de produção. O experimento foi instalado em Casa Branca, SP. Os porta-enxertos utilizados foram: tangerinas 'Cleópatra' (C. reshni) e 'Sunki' (C. sunki), citrange 'Morton' e 'Troyer' $(C$. sinensis $\times$ P. trifoliata), trifoliata 'Limeira" ( $P$. trifoliata), limão 'Cravo' (C. limonia), e limão 'Volkameriano' (C. volkameriana). Os porta-enxertos citrange 'Troyer' e trifoliata 'Limeira" foram excluídos no $11^{\circ}$ ano devido ao declínio dos citros, além de apresentarem incompatibilidade na região da enxertia no último porta-enxerto. Os porta-enxertos que apresentaram as melhores produções foram as tangerinas 'Sunki' e 'Cleópatra', respectivamente. Aos quinze anos de idade das plantas, não foi constatado declínio dos citros em nenhuma planta de 'Pera' enxertada sobre tangerina 'Sunki', mostrando esse cavalo ser tolerante a essa anormalidade. A tangerina 'Cleópatra' apresentou média tolerância ao declínio e o limão 'Cravo' mostrou-se muito sensível, sendo que os outros porta-enxertos também foram afetados. Com relação à qualidade dos frutos, não houve diferença significativa entre os porta-enxertos.

Müller et al. (1996) avaliaram características de desenvolvimento, compatibilidade e incompatibilidade da laranjeira 'Pera' (C. sinensis) clone "Bianchi" sobre doze porta-enxertos após 23 anos de plantio. Os porta-enxertos utilizados foram: tangelo 'Orlando' (C. reticulata $\times$ C. paradisi), tangerina 'Sunki' (C. sunki), laranja 'Caipira' ( $C$. sinensis), limão 'Cravo' ( $C$. limonia), citrange 'Morton' e 'Troyer' $(C$. sinensis $\mathrm{x} P$. trifoliata), limão 'Rugoso da Flórida' e 'Rugoso Nacional' (C. jambhiri), limão "Volkameriano' "Palermo", trifoliata "Davis A" e "Limeira" (P. trifoliata) e citrumelo Swingle " 4475 ”. As combinações com tangelo 'Orlando', tangerina 'Sunki' e laranja 'Caipira' foram as mais compatíveis e, de maneira geral, as de maior desenvolvimento. As combinações com citrange 'Morton' e trifoliata "Limeira" tiveram o menor desenvolvimento.

Figueiredo et al. (1997) avaliaram a produção inicial de tangor 'Murcote' sobre dezesseis porta-enxertos em duas regiões do Estado de São Paulo: Itirapina e Porto 
Feliz. Os porta-enxertos utilizados foram: limão 'Cravo', tangelo 'Orlando', laranja 'Caipira DAC', trifoliatas 'Kryder8-5' e 'EEL' e tangerinas 'Cleópatra', 'Sunki', 'Batangas', 'Oneco', 'Swatow', 'Szinkon', 'Cravo', 'Dancy', 'Suen Kat', 'Pook Ling Ming' e 'Satsuma'. O experimento foi instalado em 1990 e os resultados referem-se a produções de 1993 a 1996. Em Itirapina, não houve diferença estatística entre a maioria dos porta-enxertos. Entretanto, os porta-enxertos que proporcionaram uma maior tendência de produção, em ordem decrescente, foram: tangerina 'Cleópatra', limão 'Cravo' e tangerina 'Sunki'. Em Porto Feliz também não houve diferença estatística entre a maioria dos porta-enxertos, apresentando os porta-enxertos tangelo 'Orlando', tangerinas 'Cleópatra', 'Szinkon', 'Suen Kat' e limão 'Cravo', uma maior tendência de produção. Com relação à precocidade de produção, não foram observadas diferenças significativas.

A escolha do porta-enxerto a ser utilizado é uma fase de grande importância quando no planejamento de um pomar. Essa escolha deverá levar em conta o local de instalação do pomar, o clima, o solo a copa e o manejo a ser adotado, já que não existe um porta-enxerto ideal. Em função dessas características, será escolhido o porta-enxerto que melhor adapta-se à situação. A Tabela 1 apresenta características dos principais porta-enxertos utilizados no Brasil.

Tabela 1. Características dos principais porta-enxertos de citros:

\begin{tabular}{|c|c|c|c|c|c|c|c|c|}
\hline & $\begin{array}{l}\text { Resist. } \\
\text { Gomose }\end{array}$ & $\begin{array}{l}\text { Resist. } \\
\text { Seca }\end{array}$ & Declínio & Tristeza & $\begin{array}{l}\text { Início da } \\
\text { Produção }\end{array}$ & $\begin{array}{l}\text { Qualidade } \\
\text { dos frutos }\end{array}$ & $\begin{array}{l}\text { Vigor da } \\
\text { planta }\end{array}$ & Produção \\
\hline Limão Cravo & $\mathbf{M}$ & B & S & $\mathrm{T}$ & $\mathrm{P}$ & $\mathbf{M}$ & A & B \\
\hline $\begin{array}{l}\text { Limão } \\
\text { Volkameriano }\end{array}$ & $\mathbf{M}$ & B & $S$ & $\mathrm{~T}$ & $P$ & $\mathbf{M}$ & A & B \\
\hline Laranja Azeda & A & B & $\mathrm{T}$ & $\mathrm{S}$ & $\mathbf{M}$ & B & $\mathbf{M}$ & B \\
\hline $\begin{array}{l}\text { Tangerina } \\
\text { Cleópatra }\end{array}$ & $\mathbf{M}$ & $\mathbf{M}$ & $\mathrm{T}$ & $\mathrm{T}$ & $\mathbf{M}$ & B & A & B \\
\hline $\begin{array}{l}\text { Tangerina } \\
\text { Sunki }\end{array}$ & $\mathbf{M}$ & $\mathbf{M}$ & $\mathrm{T}$ & $\mathrm{T}$ & $\mathbf{M}$ & B & A & B \\
\hline $\begin{array}{l}\text { Citrumelo } \\
\text { Swingle }\end{array}$ & A & B & $\mathrm{T}$ & $\mathrm{T}$ & $\mathbf{M}$ & B & A & B \\
\hline $\begin{array}{l}\text { Poncirus } \\
\text { trifoliata }\end{array}$ & A & $\mathbf{M}$ & S & $\mathbf{R}$ & $\mathbf{P}$ & O & BA & B \\
\hline $\begin{array}{l}\text { Laranja } \\
\text { Caipira }\end{array}$ & BA & BA & $\mathrm{T}$ & $\mathrm{T}$ & $\mathbf{M}$ & B & A & B \\
\hline
\end{tabular}




\subsection{Melhoramento de porta-enxertos de citros}

Programas de melhoramento de porta-enxertos de citros são de grande importância para o desenvolvimento da citricultura, já que importantes características horticulturais são controladas ou influenciadas pelo porta-enxerto. Em geral esses programas dão ênfase a problemas relacionados ao solo, como seca, Phytophthora, nematóides, além de resistência ao vírus da Tristeza, declínio e diminuição do porte da copa (Davies \& Albrigo, 1994; Grosser \& Gmitter Junior., 1990a). Além das características melhoradas, a seleção para altos níveis de embrionia nucelar é muito importante para a produção de porta-enxertos uniformes e idênticos à planta mãe (Davies \& Albrigo, 1994).

Os primeiros programas de melhoramento de citros foram iniciados na Flórida em 1893 com Swingle e Webber. Desde então, numerosos programas foram desenvolvidos com diversos objetivos (Davies \& Albrigo, 1994).

Programas de melhoramento através de hibridização sexual tem tido pouco sucesso, exceto no caso de tangerinas (Spiegel-Roy \& Vardi, 1984). A falta de bons resultados através de técnicas convencionais de melhoramento dos citros se dá devido a aspectos da biologia reprodutiva deste gênero como alta heterozigosidade, esterilidade de pólen e óvulo, incompatibilidade sexual, poliembrionia nucelar e juvenilidade (Grosser \& Gmitter Jr., 1990a; Ling et al., 1989; Vardi, 1981; Vardi \& Galun, 1989; Vardi \& Spiegel-Roy, 1982; Vardi et al., 1974).

A alta heterozigosidade dos citros pode ter sido resultado de polinizações cruzadas realizadas por insetos, já que a ocorrência natural de cruzamentos intervarietais e até interespecíficos é relativamente fácil nos citros (Koller, 1994). Muitos híbridos produzidos naturalmente no campo são perpetuados pela embrionia nucelar (Davies \& Albrigo, 1994) e são fatores contribuintes para a falta de conhecimento e dificuldade de estudos genéticos dos citros.

Embora a diversidade genética dentro do gênero Citrus seja grande, as bases genéticas de certas espécies são muito limitadas. Isso é observado em laranja doce e pomelo (Gmitter Jr. et al., 1992), que eram consideradas espécies por 
Swingle (1943) e Tanaka (1954), citados por Gmitter Jr. et al. (1992), mas atualmente através de estudos morfológicos, bioquímicos e de taxonomia, propõe-se que existam apenas três ou quatro espécies verdadeiras do gênero Citrus, e que laranja doce e pomelo são híbridos interespecíficos (Barret \& Rhodes, 1976; Scora, 1975; Scora et al., 1982).

Desse modo, cruzamentos entre parentais com características complementares, frequentemente não produzem a progênie híbrida desejada. Progênies fracas são produzidas como resultado da depressão por endogamia (Barret \& Rhodes, 1976; Swingle \& Reece, 1967), onde gens deletérios antes mascarados por gens dominantes são expressos devido à segregação meiótica (Grosser \& Gmitter Junior, 1990a). Devido a esse fato, dentre os muitos híbridos obtidos por fecundação controlada pelo homem, vários eram pouco vigorosos e por isso poucos apresentam valor comercial (Moreira \& Pio, 1991). A produção contínua de descendentes zigóticos fracos e não competitivos devido à depressão por endogamia pode ter selecionado para altos níveis de embrionia nucelar (Davies \& Albrigo, 1994).

Algumas espécies do gênero Citrus apresentam esterilidade de pólen e óvulo (Soost \& Cameron, 1975), o que impede que cruzamentos sexuais sejam realizados entre essas espécies. Além disso, incompatibiidades entre espécies e gêneros próximos, impedem que certos cruzamentos obtenham sucesso (Grosser \& Gmitter Jr., 1990a).

A apomixia, via poliembrionia nucelar, ocorre em muitas variedades. A poliembrionia nucelar é a produção de diversos embriões de origem nucelar, ou seja, idênticos à planta mãe. Quando cultivares poliembriônicos são utilizados como parental materno, poucos ou nenhum "seedling" zigótico são produzidos, já que a embrionia nucelar restringe e freqüentemente anula o desenvolvimento do embrião zigótico na maturação da semente (Kobayashi \& Ohgawara, 1988). Em geral, ocorre a produção de um embrião zigótico e os outros são nucelares. Desse modo, o efeito da embrionia nucelar é que, quando se faz hibridação controlada usando clones poliembriônicos como parental materno, freqüentemente se produz pouco ou nenhuma progênie híbrida (Grosser \& Gmitter Junior, 1990a). A poliembrionia nucelar é outro empecilho ao melhoramento, já que existe a predominância de germinação dos embriões nucelares, prejudicando a germinação dos embriões zigóticos ou híbridos (Koller, 1994). 
A maioria das espécies de citros tem longo período juvenil, levando 5 ou mais anos até a primeira floração (Grosser \& Gmitter Junior, 1990a) e de 10 a 15 anos para que possam ser bem avaliadas as características de produção e qualidade dos frutos. Isso torna o melhoramento de citros muito longo, caro, além de exigir grande extensão de terra (Davies \& Albrigo, 1994; Koller, 1994).

Devido a essas dificuldades, a maioria dos cultivares copa e porta-enxerto importantes economicamente foram obtidos através de mutação e seleção de variedades já existentes e não de programas de melhoramento (Davies \& Albrigo, 1994; Gmitter Jr. et al., 1992; Grosser \& Gmitter Junior, 1990a; Hodgson, 1967; Spiegel-Roy \& Vardi, 1984). Como exemplo, temos a laranja 'Baianinha', que provavelmente é uma variação da laranja 'Baia' (Figueiredo, 1991), que por sua vez, provém de mutação da laranja 'Seleta' (Moreira \& Pio, 1991).

Pais monoembriônicos que produzem somente "seedlings" zigóticos podem ser usados para criar populações segregantes, mas o número desses parentais é pequeno, limitando drasticamente o grupo de parentais maternos que podem ser utilizados em programas de melhoramento (Grosser \& Gmitter Junior, 1990a). Como exemplos de híbridos produzidos através de hibridação natural, citam-se o tangor 'Murcote' (Citrus reticulata Blanco x Citrus sinensis L. Osbeck), citrange 'Carrizo' e 'Troyer' (Poncirus trifoliata Rafinesque $\mathrm{x}$ Citrus sinensis L. Osbeck), tangelo 'Orlando' e 'Nova' (Citrus reticulata Blanco x Citrus paradisi Macfadyen), entre outros.

As gemas de plantas cítricas apresentam mutações genéticas com certa frequência (Koller, 1994). As mutações são modificações genéticas que produzem mudanças permanentes no genótipo da planta. Mutações podem afetar o material genético nuclear (cromossomos) ou gens citoplasmáticos (plastídeos e mitocondria). Mudanças cromossômicas podem resultar de rearranjamentos de quatro bases no DNA (mutações de ponto) ou de deleções, duplicações, translocações e inversões de partes de alguns cromossomos. Mudanças podem resultar de adição ou subtração de cromossomos (aneuploidia) ou de multiplicação completa do conjunto de cromossomos (poliploidia). Mutações são preservadas durante a mitose e a produção de novas células derivadas da 
célula mutante original resulta em um novo clone dentro da planta original (Hartmann et al., 1990).

A seleção clonal baseia-se em selecionar "novas variedades" de uma variedade que mantém suas características primárias, mas com maiores produtividades, maturação mais precoce ou tardia, fruta de melhor qualidade ou outras características de interesse (Grosser \& Gmitter Junior, 1992).

Com o objetivo de induzir variações genéticas, células somáticas e zigóticas de plantas cítricas têm sido submetidas a tratamentos com raios $\mathrm{X}$ e nêutrons, raios gama $\mathrm{e}$ colchicina (Koller, 1994). Dessa forma, foram obtidas inúmeras mutações, mas nenhuma de valor comercial (Koller, 1994; Moreira \& Pio, 1991).

Em geral, os citros e outros gêneros da subfamília Aurantioideae são diplóides, com $2 n=2 x=18$ cromossomos (Cameron \& Frost, 1968; Koller, 1994; Moreira \& Pio, 1991; Spiegel-Roy \& Vardi, 1984). Triplóides e tetraplóides naturais ocorrem em baixa frequência (Spiegel-Roy \& Vardi, 1984). Plantas tetraplóides podem ser utilizadas como porta-enxerto com o objetivo de diminuir o porte da copa (Grosser \& Gmitter Junior, 1990a).

\subsection{Utilização da Biotecnologia no melhoramento de citros.}

A biotecnologia é atualmente uma opção para superar-se limitações relacionadas à biologia reprodutiva dos citros que dificultam a obtenção de variedades melhoradas através de métodos convencionais de melhoramento. De acordo com Grosser \& Gmitter : Junior, (1990a), a obtenção de sucesso no melhoramento dos citros será aumentada pelo desenvolvimento de programas que combinem métodos convencionais de melhoramento com novas biotecnologias.

Existem diversas técnicas biotecnológicas que podem ser aplicadas ao melhoramento dos citros. As principais são apresentadas a seguir. 


\subsubsection{Hibridação somática}

Protoplastos são células vegetais sem parede celular. Eles podem ter sua parede celular retirada por métodos mecânicos ou por digestão enzimática (Bengochea \& Dodds, 1986).

Protoplastos podem ser isolados a partir de diversos tecidos, como folhas, tétrades de flores (para protoplastos haplóides), calos não embriogênicos, calos embriogênicos e culturas embriogênicas em suspensão, sendo esta a fonte mais apropriada para se obter protoplastos com capacidade embriogênica (Grosser \& Gmitter Junior, 1990a).

A hibridação somática de citros através da fusão de protoplatos ultrapassa barreiras biológicas naturais à hibridação dos citros, e cria novas oportunidades que seriam dificeis ou impossíveis de ser conseguidas através de hibridação natural ou convencional (Grosser et al., 1996a). Por ser um processo aditivo, em geral resulta na formação de alotetraplóides, nos quais combina-se o genoma nuclear de ambos os parentais (Grosser \& Gmitter Junior, 1990b). Características que estão sob controle de gens dominantes ou co-dominantes em um dos parentais, têm uma boa probabilidade de serem expressas no híbrido somático, o que possibilita a produção de híbridos alotetraplóides com características complementares de ambos os parentais (Grosser \& Gmitter Junior, 1990a,b). Em contraste com a hibridação sexual, onde a herança do genoma citoplasmático (cloroplastos e mitocôndrias) é predominantemente de origem materna, o híbrido somático recebe contribuições citoplasmáticas de ambos os pais (Grosser et al. 1990b; Ohgawara \& Kobayashi, 1991). Além disso, gens recessivos deletérios que são mascarados nos pais devem permanecer mascarados e não serão expressos no híbrido somático (Gmitter Junior et al., 1992; Grosser \& Gmitter Junior, 1990a,b).

É pouco provável que híbridos somáticos tetraplóides sejam utilizados diretamente com novos cultivares, já que as frutas tetraplóides geralmente apresentam características inaceitáveis aos consumidores, como casca grossa, fruta com forma irregular e textura áspera (Gmitter Junior et al., 1992). Essas alterações morfológicas 
associadas a poliploidia podem ser toleradas em porta-enxertos, já que as mudanças não são expressas na copa enxertada nesses cavalos (Grosser et al., 1996a).

Desse modo, híbridos somáticos tetraplóides podem ser utilizados diretamente como porta-enxertos, que deverão apresentar as características complementares dos parentais e reduzir o porte da copa (Gmitter Junior et al., 1992; Grosser \& Gmitter Junior, 1990a), característica de grande interesse por reduzir os custos da colheita e possibilitar plantios mais adensados.

O sistema de produção de híbridos somáticos através de fusão de protoplastos é baseado na capacidade de regeneração de plantas via embriogênese somática a partir de calos (Motomura et al., 1995), sendo a capacidade embriogênica de um dos parentais um pré-requisito para o sucesso na obtenção de híbridos somáticos. $\mathrm{O}$ alto potencial de regeneração de plantas a partir de células embriogênicas de citros as torna material adequado para fusão de protoplastos, transformação genética e armazenamento "in vitro" de germoplasma (Kunitake \& Mii, 1995).

O método mais difundido de produção de híbridos somáticos de citros utiliza polietilenoglicol (PEG), que induz a fusão química de protoplastos isolados de calos friáveis embriogênicos de origem nucelar ou culturas de células em suspensão como um parental, com protoplastos do segundo parental isolado a partir de folhas de "seedlings" (Grosser, 1994; Grosser et al., 1996a,b). Esse método permite a fácil determinação da eficiência de fusão, pois os heterocarions (dois núcleos no citoplasma misto) podem ser facilmente identificados pela presença de marcadores distintos de ambas as fontes parentais (grãos de amido derivado de protoplastos de cultura embriogênica e cloroplastos derivados dos protoplastos de folha) (Grosser, 1993). Observando a literatura, nota-se que a maioria dos híbridos somáticos de citros foram produzidos por fusão química de protoplastos com a utilização de PEG.

Um outro método utilizado para produção de híbridos somáticos de citros, mas em menor escala, é o de fusão elétrica dos protoplastos. Por meio desse método, os protoplastos são alinhados pela aplicação de um diferencial de potencial e são então fundidos pela aplicação de um pulso de corrente direta (Bengochea \& Dodds, 1986). 
Grosser \& Gmitter Junior (1990a) recomendam o método químico de fusão de protoplastos que utiliza PEG, pois é um método simples, eficiente, barato e parece não influenciar na viabilidade dos protoplastos. Entretanto, Saito et al. (1991) comentam que o método de fusão química que utiliza PEG consome muito tempo, é complicado e tóxico para os protoplastos, e que as técnicas de eletrofusão são muito mais simples e eficientes.

A verificação da hibridação somática é geralmente feita através da contagem do número de cromossomos, análise morfológica das folhas do híbrido e análise de DNA através de marcadores moleculares. Em geral, os híbridos somáticos apresentam morfologia intermediária entre os pais e exibem maior espessamento da folha devido a natureza tetraplóide (Grosser, 1994).

A capacidade de produzir calos embriogênicos e regeneração de plantas híbridas é usualmente promovida pelo parental embriogênico, mas parece ser influenciada pelo genótipo parental de folha e estimulada pelo processo de fusão (Grosser, 1994). Calos nucelares de citros obtidos a partir de óvulos são talvez a única e a mais apropriada fonte de protoplastos embriogênicos (Vardi \& Galun, 1988). Entretanto, Hidaka \& Kajiura (1988) introduziram "in vitro" embriões de sementes jovens de espécies de citros e obtiveram calos friáveis embriogênicos da região do hipocótilo do embrião. Protoplastos isolados desses calos deram origem à plantas. Ling et al. (1989) introduziram "in vitro" anteras de Calamondin (Citrus madurensis Loureiro), das quais emergiram embriões. Alguns embriões produziram calos embriogênicos na região do hipocótilo, a partir dos quais foram isolados protoplastos, que deram origem a plântulas de calamondin.

A utilização de calos tem sido relacionada com altas taxas de variação somaclonal em diversas culturas. Entretanto, embriões de citros obtidos a partir de calos conservam a identidade genética da planta mãe e expressam pouca variabilidade (Jiménez, 1996).

Kobayashi (1987) avaliou 25 plantas de laranja 'Trovita' (Citrus sinensis L. Osbeck) obtidas de protoplastos isolados de calos nucelares. Diversas características foram avaliadas, incluindo morfologia de flor e folha, óleo da folha, padrões de 
isoenzima e número de cromossomos. Não foram encontradas variações significativas entre as plantas e a uniformidade era idêntica à de "seedlings" nucelares.

O primeiro exemplo de híbrido somático de citros, obtido por Ohgawara et al. (1985), foi um híbrido alotetraplóide produzido pela fusão de protoplastos embriogênicos de laranja 'Trovita' (C. sinensis) com protoplastos de folha de Poncirus trifoliata Rafinesque, espécies sexualmente compatíveis. A partir dessa data, um grande numero de híbridos somáticos de citros foi produzido, incluindo vários entre parentais sexualmente incompatíveis. Atualmente mais de 100 híbridos somáticos de citros foram produzidos (Grosser et al., 1996a), citando-se alguns exemplos.

Exemplos de híbridos somáticos para porta-enxerto com potencial para resistência a doenças são mencionados em Louzada et al. (1992). Esses híbridos foram produzidos pela fusão química, induzida por $\mathrm{PEG}$, de protoplastos das seguintes combinações: tangerina 'Cleópatra' (C. reshni) + laranja 'Azeda' (C. aurantium), tangerina 'Cleópatra' (C. reshni) + limão 'Rugoso' (C. jambhiri), tangerina 'Cleópatra' (C. reshni) + limão 'Volkameriano' (C. volkameriana), tangerina 'Cleópatra' (C. reshni) + limão 'Cravo' (C. limonia), laranja 'Hamlin' (C. sinensis) + limão 'Cravo' (C. limonia), laranja 'Azeda' (C. aurantiun) + limão 'Volkameriano' (C. volkameriana), híbrido de C. aurantium (Smooth Flat Seville) + limão 'Rugoso' (C. jambhiri) e laranja 'Valência' (C. sinensis) + citrange 'Carrizo' [C. paradisi x P. trifoliata]. Latado (1998), produziu também o híbrido limão 'Cravo' $(C$. limonia $)+$ tangerina 'Cleópatra' ( $C$. reshni) a ser utilizado como porta-enxerto.

Muitas espécies da subfamília dos citros são compatíveis como porta-enxerto, mas não são aceitos devido a características horticulturais indesejáveis quando usados diretamente como cavalos e muitos são sexualmente incompatíveis, impossibilitando a introdução de gens de interesse através da hibridação sexual (Grosser \& Gmitter Junior, 1990a; Grosser et al., 1996a). Híbridos somáticos com citros podem minimizar ou eliminar problemas de performance horticultural (Gmitter Junior et al., 1992; Grosser \& Gmitter Junior, 1990a), têm potencial para uso direto como porta-enxerto.

$\mathrm{O}$ primeiro híbrido somático de planta produzido entre gênero de lenhosas sexualmente incompatíveis resultou de protoplastos isolados de laranja 'Hamlin' (Citrus 
sinensis $\mathrm{L}$. Osbeck) provenientes de suspensão embriogênica com protoplastos isolados de folha de Severinia disticha (Blanco) Swing (Grosser \& Gmitter Junior, 1990a).

Espécies selvagens da subfamília das plantas cítricas (subfamília Aurantioideae) possuem importantes características de tolerância à stresses bióticos e abióticos, e boas características horticulturais. Gêneros afins são fonte de resistência ao declínio, o que não é encontrado no gênero Citrus (Gmitter Junior et al., 1992).

Com o objetivo de produzir híbridos específicos para porta-enxerto, Mourão Filho (1995) produziu os híbridos: laranja 'Succari' (Citrus sinensis L. Osbeck) + Severinia disticha (Blanco) Swing., laranja 'Hamlin' (Citrus sinensis L. Osbeck) $+S$. disticha, laranja 'Valência' (Citrus sinensis L. Osbeck) + S. disticha, tangelo 'Nova' (Citrus reticulata Blanco + Citrus paradisi Macfadyen) + S. disticha, laranja 'Succari' (Citrus sinensis L. Osbeck) + Severinia buxifolia (Poir.) Tenore, laranja 'Succari' (Citrus sinensis L. Osbeck) + Atalantia ceylanica (Am.) Oliv., laranja 'Succari' (Citrus sinensis L. Osbeck) + Feronia limonia (L.) Swing. e tangelo 'Nova' + Citropsis gilletiana Swing. \& M. Kell.

Muitas vezes, em função das características dos parentais utilizados, híbridos somáticos férteis podem também ser utilizados como fonte de pólen em cruzamentos interplóides convencionais com parentes maternos diplóides (18 cromossomos) para gerar progênie zigótica triplóide sem semente (Grosser, 1993, 1994; Grosser \& Gmitter Junior, 1990a). Triplóides de citros $(2 n=3 x=27$ cromossomos) são geralmente sem semente porque o número diferente de cromossomos interfere na meiose, produzindo gametas estéreis e inibindo desse modo o desenvolvimento do embrião e da semente (Grosser, 1993).

As sementes resultantes desses cruzamentos ( 4 x x $2 x)$ geralmente não são bem desenvolvidas e a taxa de germinação é muito baixa. Desse modo, através de resgate de embriões é possível a obtenção de "seedlings" triplóides (Grosser, et al., 1992). O resgate de embriões consiste em coletar embriões 3-4 meses após a polinização e introduzi-los "in vitro", dando condições adequadas para que germinem.

Diversos híbridos somáticos desenvolvidos com o objetivo de serem utilizados em cruzamentos interplóides já floresceram e apresentam fertilidade do grão de pólen, 
mostrando que essa característica não deve ser fator limitante para a produção de triplóides (Grosser, 1993). Exemplos híbridos somáticos produzidos com o objetivo de serem utilizados como fonte de pólen em cruzamentos com variedades diplóides monoembriônicas para a obtenção de triplóides sem sementes são citados por Grosser et al. (1992). Foram obtidos híbridos somáticos pela fusão química de protoplastos, com PEG, das seguintes combinações: tangelo 'Nova' [tangerina 'Clementina' (Citrus reticulata Blanco) $\mathrm{x}$ tangelo 'Orlando' (C. reticulata $\times$ C. paradisi)] + laranja 'Succari' (Citrus sinensis L. Osbeck) e laranja 'Hamlin' (C. sinensis) + tangerina 'Dancy' (Citrus reticulata Blanco).

Mourão Filho et al. (1996) também produziram híbridos somáticos a serem utilizados em cruzamentos interplóides com o objetivo de produzir triplóides sem sementes. As fusões de protoplastos foram induzidas pela utilização de PEG e resultaram na regeneração de plantas híbridas das seguintes combinações: laranja 'Succari' (C. sinensis) com tangerina 'Dancy' (C. reticulata), tangelo 'Minneola' (Citrus paradisi Macfadyen x Citrus reticulata Blanco), tangor 'Murcote' (C. reticulata $\times$ C. sinensis $)$, tangelo 'Page' [(Citrus paradisi $\mathrm{x}$ Citrus reticulata $) x$ Citrus reticulata $)] \mathrm{e}$ tangerina 'Ponkan' (C. reticulata).

Triplóides podem ser produzidos diretamente através de fusão de protoplastos haplóides (n) com protoplastos gaméticos diplóides (2n), ou seja, a produção de um triplóide interespecífico através da fusão de protoplastos diplóides isolados de culturas embriogênicas de variedades copa selecionadas com protoplastos gaméticos haplóides isolados de botões florais de genótipos selecionados com características complementares (Gmitter Junior et al., 1992; Grosser \& Gmitter Junior, 1990a; Grosser, 1994). Esse método teria a vantagem de reduzir o tempo requerido para se produzir triplóides, e como utiliza um genoma diplóide intacto, a segregação ou recombinação é reduzida (Grosser \& Gmitter Junior, 1990a).

A fusão de protoplastos pode dar origem a diversos produtos. Híbridos somáticos simétricos podem ser obtidos pela fusão de dois genomas nucleares de duas espécies diferentes (Gleddie, 1995). Quando o núcleo dos dois protoplastos sobrevivem independentemente no citoplasma misto, tem-se o heterocarion (Bengochea \& Dodds, 
1986). Híbridos somáticos assimétricos resultam da combinação de um genoma nuclear intacto de uma das espécies com um genoma nuclear parcialmente inativado, como é conseguido pela irradiação gama de protoplastos, de outra espécie (Gleddie, 1995). Quando todo o núcleo de um dos parentais é perdido, o que se tem é um núcleo na mistura de ambos citoplasmas, que seria um híbrido de citoplasma denominado cíbrido (Bengochea \& Dodds, 1986).

Cíbridos podem também ser obtidos da fusão de um protoplasto normal com um protoplasto sem núcleo. A enucleação geralmente é feita através de raio-X e de iodoacetamida (Bengochea \& Dodds, 1986).

Em trabalho de Yamamoto \& Kobayashi (1985), foram feitos três experimentos de fusão de protoplastos isolados de calos embriogênicos de tangerina 'Satsuma' (Citrus unshiu), variedade 'unshiu Juman', com protoplastos de mesófilo foliar de laranja 'F. N. Washington Navel' (Citrus sinensis L. Osbeck). Um dos experimentos produriu uma planta diplóide ( $2 n=18$ cromossomos) e não teraplóide ( $2 n=4 x=36$ cromossomos), como seria de se esperar $(2 n=18$ cromossomos em cada parental). Ao analisar o material genético da planta, observou-se que ela possuía o mesmo fragmento nuclear de rDNA de laranja ' $F$. N. Washington Navel' e análises de DNA de cloroplasto e mitocôndria de tangerina Satsuma, variedade 'unshiu Juman'. A partir desses resultados, concluiu-se que a planta se tratava de um cíbrido, onde o genoma nuclear era de laranja ' $\mathrm{F}$. $\mathrm{N}$. Washington Navel' e o genoma citoplasmático era de tangerina Satsuma, variedade 'unshiu Juman'.

Grosser et al. (1996a), observaram através de análises de RFLP, que plantas originadas de fusões de protoplastos de Calamondin (C. madurensis Loureiro) + laranja 'Azeda' "Keen" (C. aurantium L.), tangerina 'Cleópatra' (C. reticulata Blanco) + laranja 'Azeda' e laranja 'Valência' $(C$. sinensis L. Osbeck) + limão 'Feminello' ( $C$. limon L. Burm. F.) eram cíbridos, pois continham o núcleo do parental de folha, o genoma mitocondrial do doador obtido de calos embriogênicos e o genoma de cloroplastos de ambos os parentais.

As dificuldades que limitam o melhoramento dos citros limitam também os estudos genéticos em citros. $\mathrm{O}$ número de híbridos somáticos e sua diversidade devem 
aumentar por meio dessa técnica para maximizar a probabilidade de criar e selecionar híbridos superiores sob o ponto de vista genético e horticultural (Grosser \& Gmitter Junior, 1990b).

\subsubsection{Cultura de endosperma}

Um outro meio de se produzir plantas triplóides é pela cultura de endosperma. $\mathrm{O}$ endosperma é um tecido triplóide ( $2 n=3 x=27$ cromossomos). Esse tecido pode ser cultivado "in vitro", produzir calos e através de embriogênese somática, produzir embriões que originem plantas triplóides sem sementes (Louzada, 1990).

Gmitter et al. (1990) obtiveram plantas triplóides de laranja 'Ridge Pineapple' (Citrus sinensis L. Osbeck). Endospermas extraídos 12 a 14 dias após a antese foram introduzidos em meio de cultura para indução e proliferação de calos, indução da embriogênese somática, desenvolvimento do embrião e posteriormente plântula.

\subsubsection{Transformação genética}

A transformação genética é uma ferramenta importante para se adicionar características específicas de interesse, codificadas por um ou alguns gens para melhorar o genótipo, sem alterar a aparência ou qualidade do fruto (Grosser, 1994). Entretanto, até o momento não foi foi feita a introdução de gens de interesse agronômico no gênero Citrus.

Kobayashi \& Uchimiya (1989) transformaram calos de laranja 'Trovita' (Citrus sinensis L. Osbeck) através de transferência direta de DNA. O processo de transformação se deu pela mistura de solução de protoplastos de laranja 'Trovita' (C.sinensis) com solução de DNA contendo plasmídio pCT2T3, que continha o gen marcador de resistência à kanamicina. A introdução do DNA nos protoplastos foi promovida por solução de PEG, que foi adicionada à mistura de protoplastos com o DNA do plasmídio. Os protoplastos deram origem a colônias, que foram transferidas 
para meio de cultura seletivo com kanamicina. Não houve regeneração de plantas e a confirmação da transformação dos calos foi feita pela análise de "Southern blot".

Vardi et al. (1990) relataram a transformação de protoplastos de citros e a regeneração de plantas transgênicas. O DNA do plasmídio pCAP212, contendo os gens neomycin phosphotransferase (nptII) e chloranphenicol acetyltrasferase (cat), foi introduzido em protoplastos de limão 'Rugoso' ( $C$. jambhiri) pela utilização de solução de PEG. Plantas foram regeneradas e a confirmação da transformação se deu pela hibridização Southern e pela atividade de $n p t I I$.

Hidaka et al. (1990a,b) obtiveram plantas de citros transformadas por meio de Agrobacterium. Para isso, calos de laranja 'Washington navel' (C. sinensis), tangerina 'Ponkan' "Otha" e tangerina 'Kara' (Citrus reticulata Blanco) foram co-cultivados com 2 raças de Agrobacterium tumefaciens em meio líquido. A primeira raça continha o vetor binário pTRA415, contendo o gen neomicyn phosphotransferase II (nptII) de resistência a kanamicina e a outra continha o vetor pGV3850 : pMPK1 10-htp contendo o gen $h p t$ de resistência a higromicina. Somente calos de 'Washington Navel' e laranja 'Trovita' sobreviveram em meio de cultura com kanamicina ou higromicina. Os embriões originados nos meios de cultura seletivos foram transferidos para meio de cultura para induzir a regeneração de plântulas. Extraiu-se DNA de calos e de tecidos das plântulas para análise de Southern Blot. Por meio dessa análise, confirmou-se a presença de fragmentos complementares ao probe de resistência a kanamicina em calos de laranja 'Trovita' e 'Washington navel'. A digestão de DNA de plântulas regeneradas a partir de embriões resistentes a higromicina, confirmou a presença do gen hpt.

Moore et al. (1992, 1993) obtiveram plantas transformadas de citros através de Agrobacterium. Segmentos internodais foram co-cultivados com Agrobacterium, que continha o gen marcador $\beta$-glucoronidase (GUS) e o gen de resistência a kanamicina (nptII). As plantas que eram resistentes a kanamicina eram também GUS positivas. Duas plantas foram transferidas para solo, e a confirmação de que eram transgênicas foi feita por meio de análises "Southern blot".

Kaneyoshi et al. (1994) desenvolveram um sistema de transformação via Agrobacterium para Poncirus trifoliata. Os plasmídios utilizados foram pBI101 ou 
pBI101-012-pl, ambos contendo o gen GUS e nptII. Segmentos de hipocótilo de Poncirus trifoliata foram co-cultivados com a bactéria. Após 3 dias de co-cultivo, os segmentos foram transferidos para meio seletivo com kanamicina e com reguladores de crescimento para induzir a brotação de gemas adventícias através de organogênese. Confirmou-se a transformação das plantas regeneradas que foram analisadas por meio da expressão do gen GUS e de "Southern Blot". Com a utilização desse método, mais de 100 plantas transformadas foram regeneradas em 2 a 3 meses.

Mais recentemente, Yao et al. (1996) relataram a transformação de tangelo 'Page' [(C. paradisi $\times$ C.reticulata $) \times$ C. reticulata $)$ pela da técnica de biolística. Células embriogênicas de suspensões celulares foram bombardeadas com partículas de tungstênio com DNA de plasmídio contendo o gen uidA codificando $\beta$-glucoronidase (GUS) e $n p t \Pi$ de resistência à kanamicina. A maioria das células que apresentaram resistência a kanamicina também expressaram a atividade do gen GUS. A partir dos calos transformados, foram obtidos embriões e plântulas. A confirmação da transformação pela integração dos gens uidA e nptII no genoma de tangelo foi confirmada através de análises de PCR (polymerase chain reaction) e "Southern blot".

\subsubsection{Considerações Finais}

Em resumo, pode-se inferir que a diversificação do uso de porta-enxertos na citricultura paulista é necessária.

De acordo com a literatura examinada, não existe uma variedade porta-enxerto ideal, mas sim aquela que melhor se adapta às condições locais de cultivo dos citros.

As técnicas biotecnológicas desenvolvidas recentemente, especialmente fusão de protoplastos para hibridação somática, têm-se mostrado ferramentas importantes na integração de técnicas convencionais de melhoramento. Em especial, a hibridação somática pode ser utilizada para a formação de híbridos somáticos a partir de parentais que apresentam características complementares.

Dessa forma, os trabalhos experimentais desta dissertação obedeceram à uma sequência lógica de experimentos para contribuir para o desenvolvimento dos protocolos 
de hibridação somática para variedades brasileiras. Os estudos foram iniciados com ensaios de indução de calos embriogênicos, a serem potencialmente utilizados como fontes para isolamento de protoplastos.

Em seguida, uma série de experimentos individuais de fusão foram realizados, buscando-se a regeneração de plantas híbridas a partir de combinações importantes. Os experimentos de fusão foram complementados com estudos de embriogênese somática.

Finalmente, a regeneração e confirmação da hibridação de plantas de uma das combinações parentais é obtida. 


\section{INDUÇÃO DE CALOS EMBROGÊNICOS EM TECIDO NUCELAR DE SETE CULTIVARES DE CITROS}

\subsection{Resumo}

Nucelos de sete variedades de citros foram introduzidos em três meios de cultura diferentes para produzir calos embriogênicos das variedades tangerina 'Ponkan' e 'Cravo' (Citrus reticulata, Blanco), tangor 'Murcote' (Citrus reticulata Blanco $\mathrm{x}$ Citrus sinensis, L. Osbeck), laranjas 'Serra d'água', 'Valência', 'Natal' e 'Pera' (Citrus sinensis, L. Osbeck). Os meios de cultura testados foram: EME [Murashige \& Tucker (1969), modificado pela adição de extrato de malte (500 $\left.\mathrm{mg} \mathrm{l}^{-1}\right)$ ]; 1/2 -EME (metade da concentração dos macronutrientes de MT + metade da concentração dos macronutrientes de $\mathrm{BH}_{3}$ (Grosser \& Gmitter Junior, 1990) $+500 \mathrm{mg} \mathrm{l}^{-1}$ de extrato de malte $+1,55 \mathrm{gl}^{-1} \mathrm{de}$ glutamina]; e EBA [EME $+0,44 \mu \mathrm{M}$ 6-benzilaminopurina $+0,04 \mu \mathrm{M} 2,4 \mathrm{D}]$. Os calos

produzidos foram classificados em 3 categorias, de acordo com a friabilidade e vigor. Calos friáveis foram obtidos em tangerinas 'Ponkan' e 'Cravo' (Citrus reticulata, Blanco), tangor 'Murcote' (Citrus reticulata Blanco x Citrus sinensis, L. Osbeck), laranjas 'Serra d'água' e 'Valência' (Citrus sinensis, L. Osbeck) 120 dias após a indução dos calos. Laranjas 'Natal' e 'Pera' (Citrus sinensis, L. Osbeck) produziram calos duros não friáveis após 120 dias da indução dos calos. Houve interação significativa entre cultivar e meio de cultura afetando a indução de calos friáveis. Os meios de cultura EME e $1 / 2$ EME apresentaram os melhores resultados para tangerinas 'Cravo' e 'Ponkan' e laranja 'Serra d'água' e o meio EBA foi o melhor meio de cultura para indução de calos friáveis em tangor 'Murcote' e laranja 'Valência'. Calos friáveis de tangerinas 'Cravo' e 'Ponkan' e tangor 'Murcote' produziram protoplastos de alta qualidade após o 
isolamento. Foi possível o isolamento de protoplastos de todas as linhagens de calos friáveis obtidas, que poderão ser utilizadas em experimentos de fusão para produzir híbridos somáticos visando o desenvolvimento de variedades.

\subsection{Summary: EMBRYOGENIC CALLI INDUCTION FROM NUCELLAR TISSUE OF SEVEN CITRUS CULTIVARS}

Nucellar tissue of seven citrus varieties were introduced onto three different culture media to produce embryogenic callus. The culture media tested were: EME [Murashige \& Tucker (1969), modified, with the adition of malt extract $\left(500 \mathrm{mg} \mathrm{l}^{-1}\right)$ ]; 112 -EME (half concentration of MT + half concentration of $\mathrm{BH}_{3}$ macronutrients (Grosser \& Gmitter Junior, 1990a $)+500 \mathrm{mg} \mathrm{l}^{-1}$ malt extract $+1,55 \mathrm{~g}^{-1}$ glutamine]; e EBA [EME + $0,44 \mu \mathrm{M}$ 6-benziladenine $+0,04 \mu \mathrm{M} 2,4 \mathrm{D}$ ]. The calli produced were classified into 3 categories, according to friability and vigor. Soft friable calli were obtained in 'Cravo' and 'Ponkan' mandarins (Citrus reticulata, Blanco), 'Murcott' tangor (Citrus reticulata, Blanco x Citrus sinensis L. Osbeck), 'Serra d'água' and 'Valencia' sweet oranges (Citrus sinensis L. Osbeck) 120 days after callus induction. 'Natal' and 'Pera' sweet oranges (Citrus sinensis L. Osbeck) produced hard non friable calli 120 days after callus induction. There was a significant interaction between cultivar and media composition affecting soft friable callus induction. EME and $1 / 2$ EME media had the best results for 'Cravo' mandarin, 'Ponkan' mandarin and 'Serra d'água' sweet orange, whereas EBA was the best media composition to induce soft friable calli on 'Murcott' tangor and 'Valencia' sweet orange. Friable callus cultures of 'Cravo' and 'Ponkan' mandarins, and 'Murcott' tangor produced high quality protoplasts after isolation. All friable callus lines were amenable to protoplast isolation, and could be used in fusion experiments to produce somatic hybrids for variety development. 


\subsection{Introdução}

O Brasil ocupa a primeira posição na produção mundial de citros (FAO, 1998), mas, apesar dessa posição de liderança, as variedades brasileiras apresentam limitações quanto a qualidade dos frutos e produtividade. Outros fatores, como doenças e problemas de pragas requerem o desenvolvimento de novas variedades de citros. $\mathrm{O}$ melhoramento convencional de citros tem apresentado um desenvolvimento limitado de novas variedades copa e porta-enxerto (Grosser \& Gmitter Junior, 1990a).

Apesar da grande diversidade do gênero, a maioria das novas variedades de citros importantes atualmente originaram-se de mutação de cultivares já existentes. A falta de bons resultados através do melhoramento convencional pode ser explicada por vários aspectos da biologia do gênero Citrus e espécies selvagens da família Rutaceae, incluindo alta heterozigose, esterilidade de pólen e óvulo, incompatibiidade sexual, poliembrionia nucelar e juvenilidade (Grosser \& Gmitter Junior, 1990a).

A embriogênese somática através da fusão de protoplastos permite a hibridação de gêneros e espécies sexualmente incompatíveis, o que é sempre difícil ou impossível pelo melhoramento convencional (Grosser \& Gmitter Junior, 1990a; Grosser et al., 1996a). A fusão de protoplastos pode também ser aplicada ao melhoramento de copas, produzindo parentais tetraplóides a serem utilizados em cruzamentos $4 \mathrm{X}$ x $2 \mathrm{X}$ para desenvolver novos cultivares triplóides sem sementes (Mourão Filho et al., 1996). Protoplastos podem ser isolados de diferentes tipos de tecidos, incluindo mesófilo de folhas, calos embriogênicos, suspensões embriogênicas e calos não embriogênicos Grosser \& Gmitter Junior, 1990a).

Buscou-se neste trabalho produzir linhagens de calos embriogênicos a serem

utilizadas como fontes alternativas para isolamentos de protoplastos. Esses protoplastos poderão ser combinados com outras espécies de citros em experimentos de fusão de protoplastos para produção de híbridos somáticos.

Tecido nucelar das seguintes cultivares de citros foram cultivados para a indução de calos embriogênicos: tangerina 'Cravo' (Citrus reticulata, Blanco), tangor 'Murcote' (Citrus reticulata, Blanco x Citrus sinensis L. Osbeck), laranja 'Pera' (Citrus 
sinensis L. Osbeck), tangerina 'Ponkan' (Citrus reticulata, Blanco), laranja 'Natal' (Citrus sinensis L. Osbeck), laranja 'Serra d'água' (Citrus sinensis L. Osbeck) e laranja 'Valência' (Citrus sinensis L. Osbeck). Frutos desses cultivares foram coletados da coleção de germoplasma do Centro de Citricultura "Sylvio Moreira", em Cordeirópolis, SP, Brasil. Tangerina 'Cravo' é um cultivar muito precoce e produz frutos de tamanho médio a grande, de forma achatada, com casca solta e número de sementes de moderado a escessivo. Tangor 'Murcote' é muito cultivado no Brasil e na Florida. As plantas são vigorosas, com formato denso e folhas alongadas. Os frutos são de tamanho médio, ligeiramente achatados na base e ápice, com bastante suco e sementes (Saunt, 1990). 'Serra d'água' é um cultivar de laranja doce sem acidez, geralmente plantado, assim como as laranjas 'Pera' e 'Natal'. Laranja 'Pera' é uma variedade de meia estação, com frutos ligeiramente ovais e casca lisa. A laranja 'Natal' é muito parecida com a laranja 'Valência' na maioria das características da planta e do fruto, e ambas são cultivares de maturação tardia (Saunt, 1990).

\subsection{Material e Métodos}

Sementes em estágio inicial de desenvolvimento (seis meses após a fertilização) foram retiradas de frutos e esterilizadas em solução de hipoclorito de sódio $(1,5 \%)$ por 15 minutos e lavadas em água destilada deionizada e esterilizada. $\mathrm{O}$ tecido nucelar foi então extraído de sementes com pinça e bisturi, sob condições assépticas e cultivados em três diferentes meios de cultura. Foram introduzidos dez nucelos por placa de Petri e 5 placas por meio de cultura, totalizando 50 nucelos por tratamento e 150 nucelos por cultivar de citros.

Os meios de cultura testados foram: EME [MT (Murashige \& Tucker, 1969) modificado pela adição de extrato de malte $\left(500 \mathrm{mg}^{-1}\right)$ ] (Grosser \& Gmitter Junior, 1990a); 1/2-EME [metade da concentração de macronutrientes de MT + metade da

concentração de macronutrientes de $\mathrm{BH}_{3}+500 \mathrm{mg}^{-1}$ de extrato de malte $+1,55 \mathrm{~g} \mathrm{l}^{-1}$ de glutamina] (Grosser \& Gmitter Junior, 1990a); e EBA [EME $+0,44 \mu \mathrm{M}$ de 6-

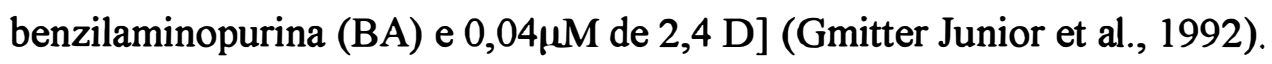


Os explantes foram cultivados em placas de Petri descartáveis $(100 \times 15 \mathrm{~mm})$, seladas com filme plásico e mantidas no escuro a $27 \mathrm{C}$. Os primeiros calos foram transferidos para meio de cultura fresco sem reguladores de crescimento (EME) a cada quatro semanas aproximadamente.

Avaliações qualitativas foram feitas a cada 120 dias após a cultura e os calos foram classificados em três categorias, baseadas na qualidade e vigor: calos duros, calos friáveis de crescimento lento e calos friáveis de crescimento rápido (dados não apresentados).

A análise estatística dos experimento de indução de calos embriogênicos foi realizada pela aplicação de um modelo logístico com superdispersão, ajustado aos dados de proporções, considerando que o número de calos friáveis tem distribuição binomial com índice igual ao número de nucelos introduzidos.

Protoplastos foram isolados de células em suspensão dos cultivares tangerina 'Cravo', tangor 'Murcote', tangerina 'Ponkan', laranja 'Serra d'água' e laranja 'Valência'. O protocolo de isolamento de protoplastos foi adaptado de Mourão Filho (1995) e utilizou aproximadamente $500 \mathrm{mg}$ de células $+2,0 \mathrm{ml}$ de meio de cultura BH3 $0.7 \mathrm{M}$ para protoplastos $+2,0 \mathrm{ml}$ de solução de enzimas. Avaliou-se o rendimento de protoplastos desses cinco cultivares pelo cálculo do número de protoplastos $/ \mathrm{ml}$ em seis repetições \pm 0 desvio padrão.

\subsection{Resultados e Discussão}

Os melhores resultados foram obtidos com tangerina 'Cravo' e tangor 'Murcote', que produziram calos friáveis de crescimento rápido em meio de cultura 1/2EME e EBA (Figura 1A). Entretanto, esses mesmos cultivares produziram calos friáveis de crescimento lento nos meios de cultura EME e EBA (Figura 1B). Calos friáveis de laranja 'Valência' foram produzidos em meio de cultura $1 / 2$-EME e EBA. Laranja 'Pera' produziu calo duro (Figura 1C) em meio de cultura EME e EBA. Em meio de cultura 1/2EME não foi observada a formação de calos para essa cultivar. Laranja 'Natal' produziu 

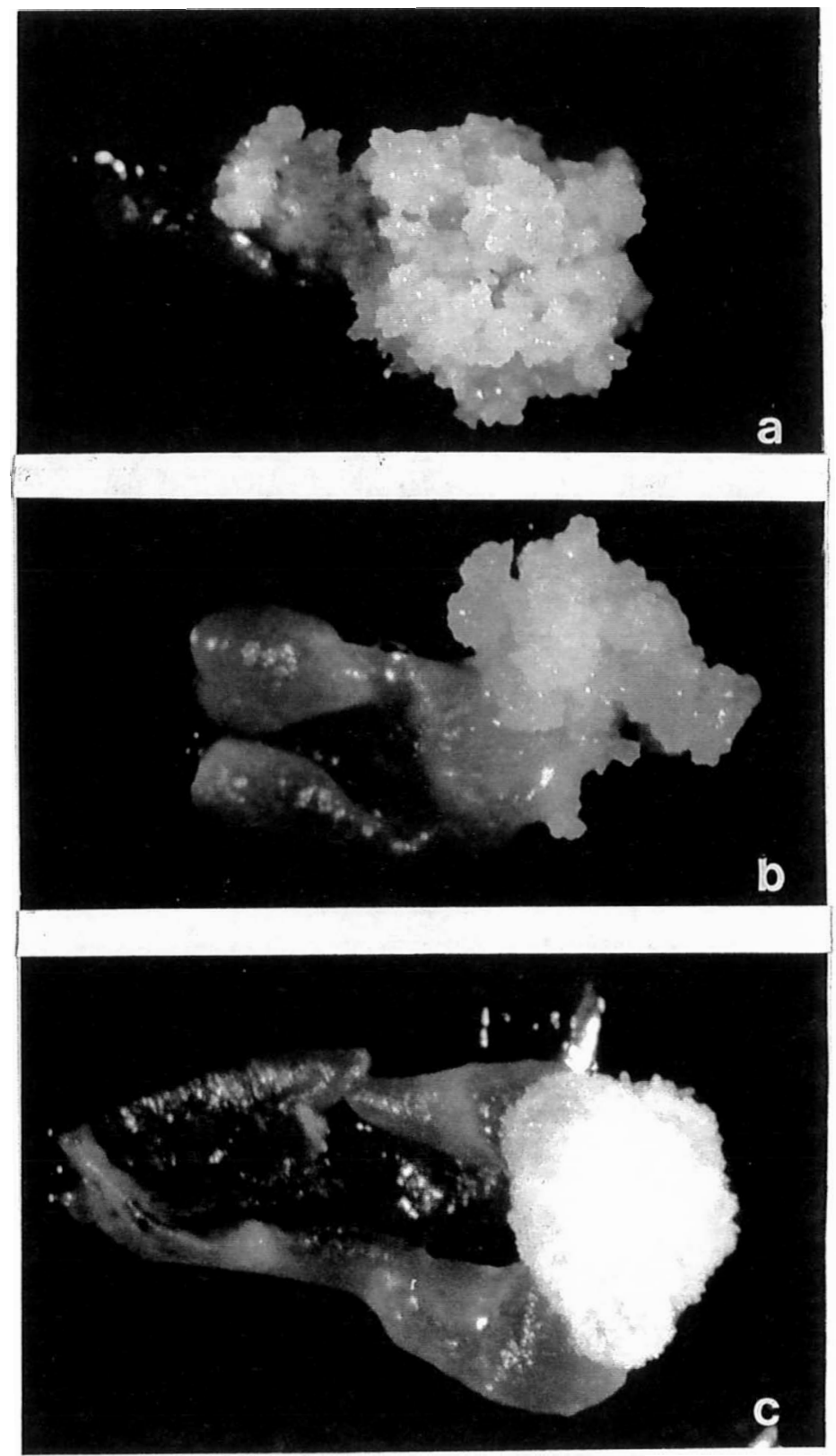

Figura 1- Tipos de calos obtidos no experimento de indução de calos embriogênicos
A. Calo friável de crescimento rápido
B. Calo friável de crescimento lento
C. Calo duro 
calos duros em todos os meios de cultura testados. Laranja 'Serra d'água' produziu alguns calos friáveis de crescimento lento em meio de cultura EME e 1/2-EME e calo duro em todos os meios testados. Tangerina 'Ponkan' produziu calos friáveis de crescimento lento em todos os meios de cultura testados e também calo duro no meio EBA. A diferente fonte de nitrogênio do meio 1/2-EME (Grosser \& Gmitter Junior, 1990a) ou a adição de reguladores no meio EME modificado (EBA) podem ter influenciado positivamente os resultados.

A adição de carvão ativado (500 $\mathrm{mg} \mathrm{l}^{-1}$ ) parece ter melhorado o vigor e a coloração dos calos de algumas variedades como a laranja 'Natal', que tinha mostrado oxidação e crescimento lento (dados não apresentados). Após dois subcultivos, melhor crescimento e friabilidade foram observados nessas cultivares. Mourão Filho \& Grosser (1992) também demonstraram efeito positivo do carvão ativado na performance de calos, na qualidade e vigor de espécies diferentes da família Rutaceae.

Foram feitas também avaliações quantitativas após 120 dias de subcultivo. Um modelo logístico de superdispersão foi adaptado às proporções de resposta dos nucelos à calos friáveis de crescimento rápido e lento (combinados) para cinco cultivares de citros (somente aqueles que não apresentaram número igual a zero em todas as contagens). Foi considerado que o número de calos friáveis tinham uma distribuição binomial com o índice igual ao número de nucelos cultivados.

Tabela 2. Análise de "deviance" para dados de indução de calos embriogênicos de sete cultivares diferentes de citros em três meios de cultura diferentes após 120 dias de cultivo.

\begin{tabular}{|c|c|c|c|}
\hline C.V. & G.L. & "Deviance" & $\mathrm{F}$ \\
\hline Cultivar $\mid$ Meio de cultura ${ }^{1}$ & 4 & 74.17 & $17.4^{* *}$ \\
\hline Meio de cultural Cultivar ${ }^{2}$ & 2 & 0.25 & $0.12 \mathrm{~ns}$ \\
\hline Cultivar.Meio de cultura $^{3}$ & 8 & 31.91 & $3.75^{* *}$ \\
\hline Erro & 56 & 59.59 & \\
\hline
\end{tabular}

${ }^{\text {I}}$ Cultivar ajustado ao meio de cultura

${ }^{2}$ Meio de cultura ajustado ao cultivar

${ }^{3}$ Interação cultivar meio de cultura 
A análise de "deviance" mostra que houve uma interação significativa entre cultivares e composição do meio de cultura (Tabela 2).

Os meios de cultura EME e 1/2-EME foram os melhores para tangerinas 'Cravo' e 'Ponkan' e para laranja 'Serra d'água', sendo que o meio de cultura EBA foi o melhor para a indução de calos friáveis para tangor 'Murcote' e laranja 'Valência' (Figura 2). A indução de calos friáveis não ocorreu nos cultivares laranja 'Pera' e 'Natal' (dados não apresentados).

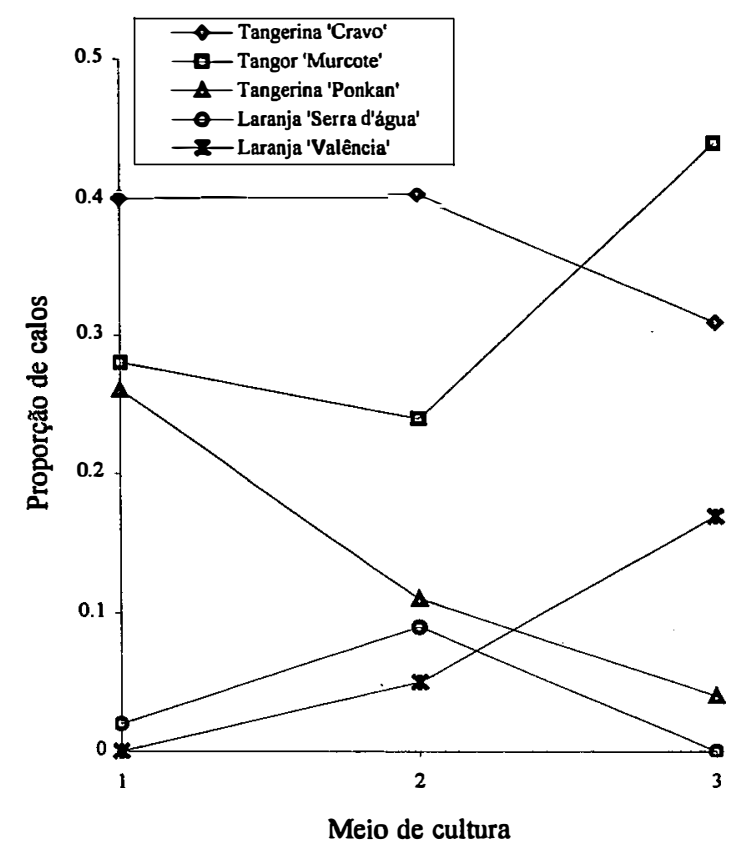

Figura 2 - Proporção de resposta de tecido nucelar à indução de calos friáveis (de crescimento lento e rápido) de cinco cultivares de citros em três meios de cultura diferentes, após 120 dias de cultivo. Meio de cultura 1 = EME; meio de cultura 2 = 1/2-EME; meio de cultura $3=$ EBA.

Efeitos do cultivar e da composição do meio de cultura na indução de calos de citros, vigor e qualidade foram previamente descritos. O meio de cultura MT suplementado com extrato de malte também induziu a formação de calos embriogênicos 
de laranja 'Shamouti' (Citrus sinensis L. Osbeck) mas falhou com laranja 'Valência' e pomelo Marsh (Citrus paradisi Macfadyen) (Kochba et al., 1972). Mourão Filho \& Grosser (1992) relataram os resultados de indução de calos não embriogênicos, friabilidade e vigor de 30 seleções diferentes de citros e espécies selvagens da família Rutaceae. Os explantes foram esterilizados e cultivados em cinco meios de cultura para indução de calos não embriogênicos. Calos friáveis foram obtidos em várias espécies, incluindo Aegle marmelos (L.), Afraegle gabonensis (Swing.) Engl., Afraegle panicullata (Schum.) Engl., Balsamocitrus daweii Stapf., Citropsis gilletiana Swing. \& M. Kell., Citrus jambhiri Lush. (limão 'Rugoso'). Oliveira et al. (1994) também demostraram a influência do genótipo e da composição do meio de cultura na indução de calos embriogênicos. O meio de cultura MT suplementado com ácido indol acético (AIA) e kinetina induziram melhor resposta de nucelos à formação de calos embriogênicos em tangerina 'Cleópatra' (Citrus reticulata, Blanco) e limão 'Cravo' (Citrus limonia, L. osbeck). Os mesmos autores constataram que não houve indução de calos de Poncirus trifoliata em nenhum dos meios de cultura testados (MT + extrato de malte, MT + AIA + kinetina, MT + BA).

Os melhores calos obtidos no presente trabalho foram selecionados e subcultivados em meio EME para o estabelecimento de linhagens apropriadas ao isolamento de protoplastos. Protoplastos foram obtidos em 5 dos 7 cultivares testados (Tabela 3). Entretanto, alto rendimento foi obtido somente em tangerina 'Cravo', tangor 'Murcote' e tangerina 'Ponkan'.

Culturas em suspensão foram iniciadas de diferentes linhagens de calos. Após três a quatro subcultivos, culturas de células em suspensão de laranja 'Valância' e laranja 'Serra d'água' apresentaram desenvolvimento de grande número de embriões, mostrando sua capacidade embriogênica. Mourão Filho \& Grosser (1992) também apresentaram isolamento de protoplastos logo após a indução de calos. Os melhores resultados foram obtidos sempre de calos friáveis. 
Tabela 3. Rendimento de protoplastos de culturas de calos embriogênicos de cinco cultivares selecionados.

\begin{tabular}{ll}
\hline Variedade & Rendimento' $^{1}$ \\
\hline Tangerina 'Cravo' & $8.3 \times 10^{5} \pm 1.3$ \\
\hline Tangor 'Murcote' & $9.6 \times 10^{5} \pm 3.3$ \\
\hline Tangerina 'Ponkan' & $9.2 \times 10^{5} \pm 4.0$ \\
\hline Laranja 'Serra d'água' & $1.1 \times 10^{4} \pm 0.7$ \\
\hline Laranja 'Valência' & $1.2 \times 10^{4} \pm 0.9$
\end{tabular}

${ }^{\mathbf{I}}$ Produção aproximada de $500 \mathrm{mg}$ de calos friáveis. Valores representam a média de protoplastos $/ \mathrm{ml} \pm$ desvio padrão de seis repetições.

\subsection{Conclusões}

Conforme os resultados obtidos, pode-se concluir que:

1) A resposta das sete variedades de citros nos três diferentes meios de cultura foi variável. Houve interação entre meio de cultura e a variedade estudada.

2) Tangerina 'Cravo' e tangor 'Murcote' mostraram os melhores resultados, produzindo calos friáveis de crescimento rápido 120 dias após o início do experimento nos meios EME e 1/2-EME (tangerina 'Cravo') e EBA (tangor 'Murcote').

3) Os calos embriogênicos friáveis das variedades tangerina 'Cravo', tangor 'Murcote' e tangerina 'Ponkan' apresentaram bom rendimento no isolamento de protoplastos e poderão ser utilizados em experimentos de fusão química de protoplastos para produção de hibridos somáticos. 


\section{EFEITO DE DIFERENTES FONTES DE CARBONO NO ESTÍMULO À EMBRIOGÊNESE SOMÁTICA DE CALOS OBTIDOS DE FUSÃO DE PROTOPLASTOS DE CITROS.}

\subsection{Resumo}

Buscou-se avaliar o efeito dos açúcares lactose $(0,145 \mathrm{M})$, maltose $(0,145 \mathrm{M})$, galactose $(0,1 \mathrm{M})+$ sorbitol $(0,1 \mathrm{M})$ e sacarose $(0,145 \mathrm{M})$ no estímulo da embriogênese somática de calos obtidos de fusão química de protoplastos das combinações laranja 'Caipira' (Citrus sinensis L. Osbeck) + tangerina 'Cleópatra' (Citrus reshni Hort. ex Tanaka), laranja 'Caipira' (C. sinensis) + limão 'Rugoso da Flórida' (Citrus jambhiri Lushington), laranja 'Pera' (Citrus sinensis L. Osbeck) + tangerina 'Cleópatra' (C. reshni) e limão 'Cravo' (Citrus limonia L. Osbeck) + laranja 'Azeda' (Citrus aurantium L.). $\mathrm{O}$ meio de cultura básico utilizado foi MT $+500 \mathrm{mg} \mathrm{l}^{-1}$ de extrato de malte (MT modificado), introduzindo-se 500mg de calo em cada placa de Petri de meio de cultura MT modificado + açúcar testado. Os calos foram mantidos sob iluminação indireta (150 lux), com fotoperíodo de $16 \mathrm{~h}$ e temperatura de $27 \mathrm{C}$. O material foi avaliado 60 dias após a introdução. Observou-se que a maltose foi o açúcar que melhor estimulou a embriogênese somática em todas as combinações de fusão, seguido pela lactose, galactose + sorbitol e sacarose respectivamente, exceto na combinação laranja 'Pera' + tangerina 'Cleópatra', onde o segundo melhor açúcar foi galactose + sorbitol em vez de lactose.

4.2 Summary: Effect of different carbon sources on induction of somatic embryogenesis in citrus protoplast fusion derived calli 
The effect of lactose $(0.145 \mathrm{M})$, maltose $(0.145 \mathrm{M})$, galactose $(0.1 \mathrm{M})+$ sorbitol $(0.1 \mathrm{M})$ and sucrose $(0.145 \mathrm{M})$ on somatic embryiogenesis induction of protoplast fusion derived calli of 'Caipira' sweet orange (Citrus sinensis L. Osbeck) + 'Cleopatra' mandarin (Citrus reshni Hort. ex Tanaka), 'Caipira' sweet orange (C. sinensis) + 'Florida Rough' lemon (Citrus jambhiri Lushington), 'Pera' sweet orange (Citrus sinensis L. Osbeck) + 'Cleopatra' mandarin (C. reshni) and 'Rangpur' lime (Citrus limonia L. Osbeck) + 'Sour' orange (Citrus aurantium L.) combinations were selected for the study. The basic culture media used was MT + malt extract $\left(500 \mathrm{mg} \mathrm{l}^{-1}\right)$ (modified MT) and calli (500 mg) were introduced on each Petri dish with MT modified media + tested sugar. Calli were mantained on indirect ilumination (150 lux), with day length of $16 \mathrm{~h}$ and $27 \mathrm{C}$ of temperature. The material was evaluated after 60 days of culture. It was observed that maltose was the best sugar that estimulated somatic embryogenesis in the all protoplast fusion combination, followed by lactose, galactose + sorbitol and sucrose, except on 'Pera' sweet orange + 'Cleopatra' mandarin combination, were the second best saccharid was galactose + sorbitol rather than lactose.

\subsection{Introdução}

A regeneração de plantas de citros a partir de calos ou células em suspensão ocorre via embriogênese somática, isto é, pela formação de embriões semelhantes ao embrião zigótico, que desenvolvem-se e dão origem a plantas normais (Ling \& Iwamasa, 1997). Entretanto, uma série de fatores influenciam a indução e o desenvolvimento do embrião

$\mathrm{O}$ entendimento e controle dos processos que determinam e organizam a embriogênese somática podem apresentar grande importância para o melhoramento e desenvolvimento de novos cultivares de citros por meio da biotecnologia; isso porque células embriogênicas são utilizadas em culturas de protoplastos, hibridação somática, transformação genética, além de preservação "in vitro" de germoplasma por meio de embriões somáticos e calos embriogênicos (Kunitake \& Mii, 1995) . 
A embriogênese somática é utilizada como ferramenta essencial para a regeneração de híbridos somáticos produzidos por de fusão de protoplastos para o melhoramento de porta-enxertos de citros.

Entre os fatores que influenciam a embriogênese somática dos citros, a fonte de carbono do meio de cultura tem se mostrado bastante importante. A sacarose, normalmente a $5 \%(0,145 \mathrm{M})$ é a fonte de carbono utilizada com maior frequência em meios de cultura para indução à embriogênese somática em citros (Grosser \& Gmitter Junior, 1990a; Grosser et al., 1996a; Grosser et al., 1996b; Jumin \& Nito, 1996a,b; Kobayashi \& Ohgawara, 1988; Mourão Filho et al., 1996; Ohgawara et al., 1994; Vardi, 1981; Vardi et al., 1986; Yamamoto \& Kobayashi 1995).

Diversos trabalhos da literatura mostram que a embriogênese somática de calos de citros foi estimulada quando a sacarose do meio de cultura é substituída por outras fontes de carbono. Ling et al., (1990) e Kunitake et al., (1991) observaram que a embriogênese somática de tangerina 'Satsuma' (Citrus unshiu Marc.) ocorreu somente na presença de lactose.

Galactose e outros açúcares que produzem galactose no metabolismo, como lactose e raffinose mostraram-se eficientes em estimular a embriogênese somática de citros (Kochba et al., 1978).

A eficiência dos açúcares em estimular a embriogênese somática está relacionada também ao genótipo, como demonstrado em Kochba et al. (1982), onde a utilização de galactose resultou em maior número de embriões em Citrus limon e Citrus nobilis, enquanto que o maior número de embriões em Citrus sinensis e Citrus aurantium $\mathrm{L}$. foi obtido na presença de lactose.

Buscou-se no presente trabalho estudar o efeito de diferentes fontes de carbono no estímulo à embriogênese somática de calos obtidos em experimentos de fusão de protoplastos de citros. 


\subsection{Material e Métodos}

Isolamento, purificação, fusão, plaqueamento e cultura dos protoplastos

Protoplastos foram isolados de suspensão celular embriogênica e de mesófilo foliar de plântulas cultivadas "in vitro".

Calos embriogênicos foram introduzidos em meio de cultura MT (Murashige \& Tucker, 1969) modificado (modificado pela adição de $500 \mathrm{mg} \mathrm{l}^{-1}$ de extrato de malte) e mantidos sob agitação $(100 \mathrm{rpm})$ no escuro, dando origem à cultura de células em suspensão.

As plântulas foram obtidas a partir de germinação "in vitro" de sementes maduras em meio de cultura RMAN (Grosser \& Gmitter Junior, 1990a). A germinação das sementes e desenvolvimento das plântulas se deram a 27C, com fotoperíodo de 16 horas de luz.

Os isolamentos de protoplastos de suspensão celular embriogênica e de mesófilo foliar foram realizados através da metodologia de Mourão Filho (1995), utilizando solução enzimática composta por manitol $(0,7 \mathrm{M}), \mathrm{CaCl}_{\mathbf{2}}(24,5 \mathrm{mM})$, $\mathrm{NaH}_{2} \mathrm{PO}_{4}(0,92 \mathrm{mM})$, MES (6,15 mM), celulase (Onozuka RS, 1\%), macerase (1\%) e pectoliase $\mathrm{Y}-23(0,2 \%)$, diluída em meio de cultura $\mathrm{BH}_{3}$. $\mathrm{O}$ isolamento dos protoplastos ocorreu em 14 horas de incubação, sob agitação de 40 rpm no escuro.

A purificação dos protoplastos foi feita pela passagem dos protoplastos por peneira de nylon $(50 \mu \mathrm{m})$, centrifugações a $100 \mathrm{~g}$ e gradiente sacarose (25\%)-manitol (13\%), em meio de cultura CPW.

Os protoplastos de mesófilo foliar e suspensão celular purificados foram diluídos para a densidade de $2 \times 10^{5}$ protoplastos $/ \mathrm{ml}$. Misturou-se igual volume de protoplastos de mesófilo foliar e suspensão celular embriogênica. Colocaram-se 2 gotas da mistura de protoplastos em placa de Petri descartável $(58 \times 15 \mathrm{~mm})$. A fusão dos protoplastos foi feita através de método químico, utilizando solução de polietilenoglicolPEG (pm=1450) (26,6 mM). Após a fusão, foram feitas lavagens com meio de cultura $\mathrm{BH}_{3}$ 0,7M e os protoplastos foram plaqueados em meios de cultura líquidos $\mathrm{BH}_{3} 0,7 \mathrm{M}$ e EME 0,7M. 
Aproximadamente 20 dias após a fusão, adicionou-se o meio de cultura 1:1:1 (v:v:v), composto por 1 parte de $\mathrm{BH}_{3}$ 0,6M, 1 parte de MT líquido 0,6 e 1 parte de MT 0,145M modificados, com o objetivo de iniciar a redução do potencial osmótico do meio. Em subcultivos posteriores (a cada 20-30 dias), quando a cultura de protoplastos já estava mais vigorosa, adicionou-se o meio de cultura 1:2 (v:v), que é composto 1 parte do meio de cultura $\mathrm{BH}_{3}$ 0,6M e 2 partes de MT 0,145M modificado.

\section{Indução da embriogênese somática}

Os microcalos originados foram transferidos para meio de cultura MT modificado para a formação de maior quantidade de calos. Os microcalos deram origem a calos em aproximadamente um mês. Após esse período, os calos foram introduzidos nos meios de cultura com diferentes açúcares, como fontes alternativas de carbono.

O meio de cultura básico utilizado foi o MT modificado (MT $+500 \mathrm{mg} \mathrm{l}^{-1} \mathrm{de}$ extrato de malte), alterando-se a fonte de carbono disponível no meio. Os meios de cultura testados foram: MT modificado $+0,145 \mathrm{M}$ de sacarose, MT modificado + 0,145M de lactose (Kochba et al., 1978), MT modificado + 0,145M de Maltose e MT modificado $+0,1 \mathrm{M}$ de galactose $+0,1 \mathrm{M}$ de sorbitol (Yao et al., 1996). Adotou-se como padrão a mesma molaridade para todos os açúcares, exceto para a combinação galactose + sorbitol, onde adotou-se a concentração previamente utilizada por Yao et al. (1996).

Foram feitas 6 repetições de cada combinação de calos de fusão em cada meio de cultura. Os calos (500 mg) foram introduzidos em placa de Petri $100 \times 15 \mathrm{~mm}$ que continham os meios de cultura. O material foi mantido em sala de crescimento sob iluminação indireta, com fotoperíodo de 16 horas e temperatura de $27 \mathrm{C} \pm 1$.

Os calos foram subcultivados a cada 4 semanas, quando foram transferidos para meio de cultura fresco e mantidos no mesmo meio de cultura em que foram introduridos. Foram feitas avaliações do material, onde observou-se o efeito de cada meio de cultura sobre a embriogênese em cada combinação de parentais de fusão de protoplastos. 


\subsection{Resultados e Discussão}

Uma série de experimentos individuais de fusão foram realizados para a hibridação somática e regeneração de plantas. A Tabela 4 apresenta as combinações escolhidas e o número de experimentos individuais de fusão realizados para cada uma delas.

Tabela 4. Combinações parentais selecionadas para experimentos de fusão de protoplastos.

\begin{tabular}{lll}
\hline Parental embriogênico & Parental não embriogênico & $\begin{array}{l}\text { Número de experimentos de } \\
\text { fusão }\end{array}$ \\
\hline Laranja 'Pera' & laranja 'Azeda' & 5 \\
Laranja 'Pera' & tangerina 'Cleópatra' & 7 \\
Laranja 'Pera' & limão 'Cravo' & 6 \\
Laranja 'Pera' & tangerina 'Sunki' & 6 \\
Laranja 'Caipira' & tangerina 'Sunki' & 4 \\
Laranja 'Caipira' & laranja 'Azeda' & 1 \\
Laranja 'Caipira' & citrange 'Carrizo' & 1 \\
Laranja 'Caipira' & limão 'Cravo' & 2 \\
Laranja 'Caipira' & limão 'Rugoso da Flórida' & 1 \\
Laranja 'Caipira' & tangerina 'Cleópatra' & 5 \\
Laranja 'Valência' & tangerina 'Sunk' & 2 \\
Laranja 'Valência' & tangerina 'Cleópatra' & 1 \\
Tagerina 'Cravo' & tangerina 'Sunki' & 1 \\
Tagerina 'Cravo' & tangerina 'Cleópatra' & 1 \\
Tagerina 'Cravo' & limão 'Cravo' & 1 \\
Tangerina 'Cleópatra' & tangerina 'Sunki' & 1 \\
Tangerina 'Cleópatra' & limão 'Cravo' & 1 \\
Tangor 'Murcote' & tangerina 'Cleópatra' & 1 \\
Lima 'Serra d'água' & limão 'Cravo' & 2 \\
Limão 'Cravo' & tangerina 'Cleópatra' & 1 \\
Limão 'Cravo' & laranja 'Azeda' & 1 \\
\hline & & \\
& & \\
\hline
\end{tabular}


O critério para a escolha da combinação levou em consideração as características complementares dos dois parentais para o desenvolvimento de novas variedades de citros, com ênfase à busca de novos cultivares porta-enxertos.

Dentre as combinações de fusões realizadas, foram escolhidas as seguintes para realização dos ensaios de embriogênese: laranja 'Caipira' + tangerina 'Cleópatra', laranja 'Caipira' + limão 'Rugoso da Flórida', laranja 'Pera' + tangerina 'Cleópatra' e limão 'Cravo' + laranja 'Azeda'. Essas combinações foram escolhidas devido ao intenso desenvolvimento de calos que apresentavam em meio de cultura EME com sacarose, que foi o meio inicialmente utilizado para a indução da embriogênese somática.

Para a indução à embriogênese a partir de calos embriogênicos de citros, o fator talvez mais importante é a resposta dos calos a diversos açúcares (Kunitake \& Mii, 1995). A sacarose promove crescimento muito bom de calos de citros (Button, 1978), mas em experimentos de Kochba et al. (1982), a sacarose foi o açúcar que menos estimulou a embriogênese somática, a qual somente ocorreu nos níveis mais baixos testados $(8 \mathrm{mM})$. Essas observações foram confirmadas nesse experimento, onde todas as combinações de fusão de protoplastos mantidas na presença de sacarose apresentaram número muito baixo de embriões ou nenhum quando comparadas com outros açúcares (Tabela 5).

De acordo com a Tabela 5, pode-se observar também que as combinações que tiveram como parental embriogênico a laranja 'Caipira' (Figura 3A e 3B) apresentaram número de embriões muito maior do que as combinações com laranja 'Pera' (Figura 3C) e limão 'Cravo' como parentais embriogênicos, independente do açúcar utilizado. Entre os fatores que podem ter influenciado esse fato, o genótipo é um dos mais importantes, já que a capacidade embriogênica pode variar muito em genótipos diferentes dentro de uma espécie (Merkle et al., 1995). 
Tabela 5. Número médio de embriões obtidos por combinação de calos de fusão de protoplastos em cada meio de cultura após 60 dias de cultivo \pm desvio padrão de seis repetições.

\begin{tabular}{|c|c|c|c|c|}
\hline Combinação & Sacarose & Maltose & Lactose & Galactose + Sorbitol \\
\hline $\begin{array}{l}\text { Laranja 'Caipira' + tangerina } \\
\text { 'Cleópatra' }\end{array}$ & $0.5 \pm 1.22$ & $143.8 \pm 62.7$ & $40 \pm 59.2$ & $22 \pm 33.0$ \\
\hline $\begin{array}{l}\text { Laranja 'Caipira' + limão } \\
\text { Rugoso da Flórida }\end{array}$ & $2.3 \pm 4.8$ & $109.5 \pm 73.3$ & $34.6 \pm 45.3$ & $15.5 \pm 27.8$ \\
\hline $\begin{array}{l}\text { Laranja 'Pera' + tangerina } \\
\text { 'Cleópatra' }\end{array}$ & 0 & $14.5 \pm 16$ & 0 & $1 \pm 2.4$ \\
\hline $\begin{array}{l}\text { Limão 'Cravo' + laranja } \\
\text { 'Azeda' }\end{array}$ & 0 & $9.5 \pm 12.1$ & $2.5 \pm 6.1$ & $0.3 \pm 0.8$ \\
\hline
\end{tabular}

*Os valores desta tabela representam a média de seis repetições \pm o desvio padrão.

De acordo com os dados da Tabela 5, pode-se observar ainda a grande eficiência e superioridade da maltose em estimular embriogênese das combinações de fusão de protoplastos testadas quando comparada com os outros açúcares. Strickland et al. (1987) utilizaram a maltose na indução da embriogênese somática de alfafa e obtiveram resgate de grande número de embriões dessa espécie quando esse açúcar foi adicionado ao meio de cultura na presença de $\mathrm{NH}_{4}{ }^{+}$.

Nas combinações laranja 'Caipira' + tangerina 'Cleópatra', laranja 'Caipira' + limão 'Rugoso da Flórida' e limão 'Cravo' + laranja 'Azeda', a lactose foi o segundo melhor açúcar na indução à embriogênese somática. Na combinação laranja 'Pera' + tangerina 'Cleópatra' não foi observado nenhum embrião na presença de sacarose e lactose . A combinação limão 'Cravo' + laranja 'Azeda' apresentou-se muito oxidada em todos os meios de cultura e devido a isso, os embriões não desenvolveram-se bem e não são mostrados no trabalho (dados não apresentados).

Em trabalho de Anker (1974), observou-se que galactose e outros açúcares que produzem galactose como lactose e rafinose inibiram a síntese de auxina em Avena coleoptilis. Kochba et al. (1977), observaram que inibidores de auxina estimularam a embriogênese somática de calos embriogênicos de laranja 'Shamouti' (C. sinensis). Em complementação a esse trabalho e com os dados de Anker (1974), Kochba et al. (1978) incorporaram os açúcares galactose, rafinose e lactose ao meio de cultura MS e 
observaram que esses açúcares estimularam a embriogênese quando utilizados na proporção de 1 a 5\% no meio de cultura, comprovando novamente os resulados de Anker (1974).

A combinação galactose + sorbitol ocupou, em geral, a terceira posição em estímulo a embriogênese, exceto na combinação laranja 'Pera' + tangerina 'Cleópatra', onde ficou em segundo lugar. Yao et al. (1996) relataram a indução da embriogênese somática e a germinação de embriões de tangelo 'Page' [(Citrus paradisi Macfadyen $\mathrm{x}$ Citrus reticulata Blanco) x Citrus reticulata Blanco)] em meio de cultura com $0,1 \mathrm{M}$ de galactose $+0,1 \mathrm{M}$ de sorbitol. Lactose e galactose foram os açúcares mais eficientes em estimular a embriogênese somática das espécies cítricas laranja 'Shamouti' (Citrus sinensis L. Osbeck), laranja 'Navel' (Citrus sinensis L. Osbeck), tangerina 'King' (Citrus nobilis Loureiro), limão 'Vilafranca' (Citrus limon L.) e laranja 'Azeda' (Citrus aurantium L.) (Kochba, 1982) e galactose especificamente em Citrus deliciosa (Cabasson et al., 1995). Além do efeito estimulatório da embriogênese somática em espécies do gênero Citrus, a lactose apresentou esse mesmo efeito em calos de seis gêneros da subfamília Aurantioideae (Ling \& Iwamasa, 1997). 

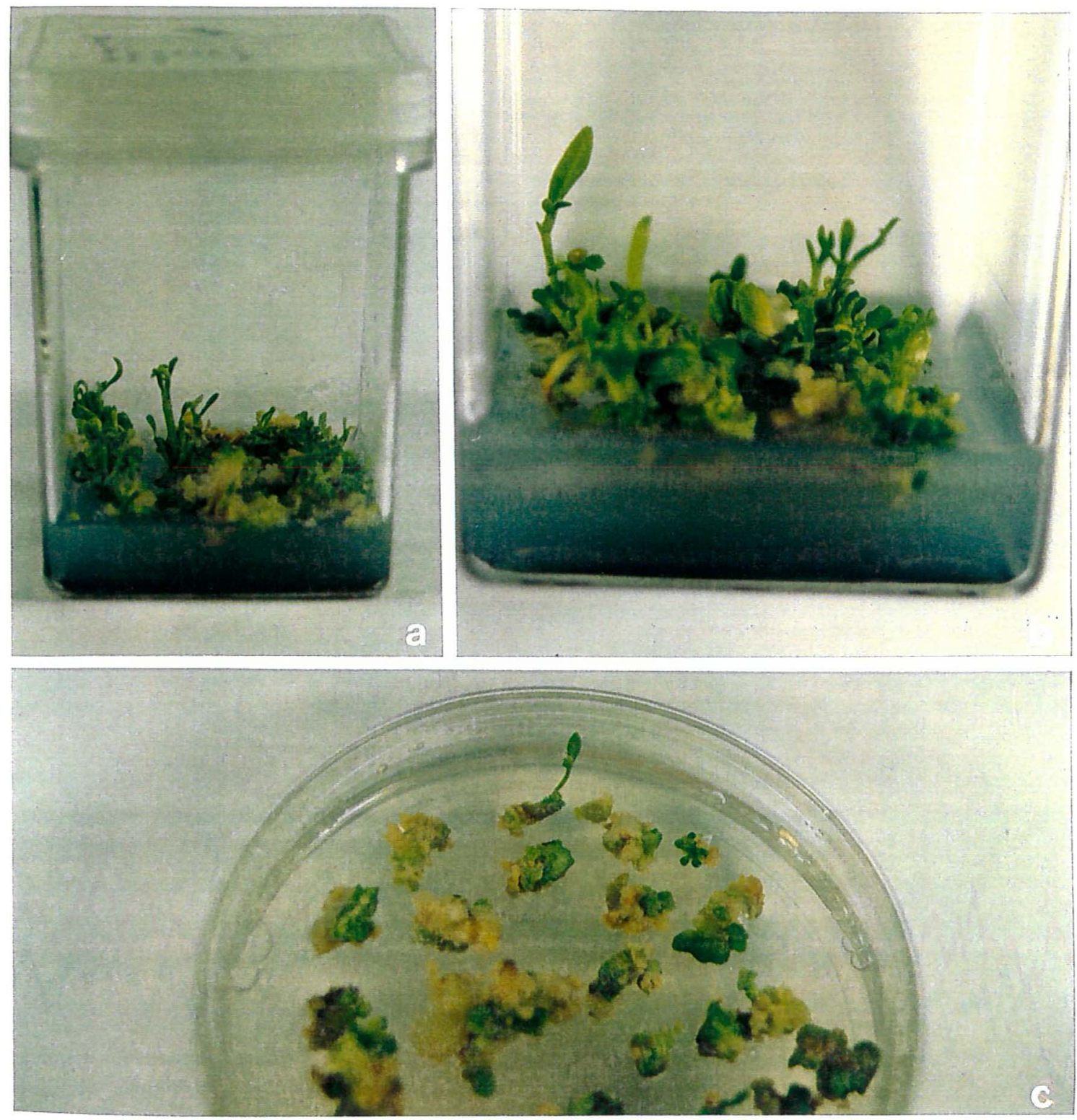

Figura 3 - Embriões em fase de germinação das combinações laranja 'Caipira' + limão 'Rugoso da Flórida' (A), laranja 'Caipira' + tangerina 'Cleópatra' (B) e laranja 'Pera' + tangerina 'Cleópatra' (C). 


\subsection{Conclusões}

De acordo com os dados obtidos neste trabalho, concluiu-se que:

1) $\mathrm{O}$ açúcar que melhor estimulou a embriogênese somática das diversas combinações de calos de fusão de protoplastos foi a maltose, embora esse efeito tenha sido mais intenso em algumas combinações.

2) A sacarose foi o açúcar que menos estimulou a embriogênese, produzindo o menor número de embriões. 


\section{HIBRIDAÇÃO SOMÁTICA ENTRE LARANJA 'CAIPIRA’ E LIMÃo 'CRAVO’ ATRAVÉS DE FUSÃO DE PROTOPLASTOS}

\subsection{Resumo}

Protoplastos de laranja 'Caipira' foram isolados de cultura de células embriogênicas em suspensão e protoplastos de limão 'Cravo' foram isolados de mesófilo foliar de plântulas germinadas "in vitro". A solução enzimática utilizada para o isolamento de protoplastos foi composta por manitol $(0,7 \mathrm{M}), \mathrm{CaCl}_{2}(24,5 \mathrm{mM})$, $\mathrm{NaH}_{2} \mathrm{PO} 4(0,92 \mathrm{mM})$, M.E.S. $(6,15 \mathrm{mM})$, celulase Onozuka RS (1\%), macerase (1\%) e pectoliase Y-23 $(0,2 \%)$. A purificação dos protoplastos foi feita com de gradiente sacarose (25\%)-manitol (13\%) em meio de cultura CPW. A indução da fusão dos protoplastos, por via química, envolveu a utilização de $26,6 \mathrm{mM}$ de polietilenoglicol (PEG) $(\mathrm{PM}=1450)$. O plaqueamento e cultivo dos protoplastos foram feitos em meio de cultura líquido. Os microcalos foram transferidos para meio EME semi-sólido. A embriogênese somática foi observada após 60 dias de cultivo. A germinação dos embriões deu-se em meio de cultura $\mathrm{EME}+0,5 \mathrm{mg} \mathrm{l}^{-1}$ de $\mathrm{GA}_{3}$. A confirmação da hibridação de 4 das 39 plantas regeneradas foi feita por meio de análise da morfologia foliar, contagem do número de cromossomos e análise de marcadores moleculares do tipo RAPD.

\subsection{Summary: SOMATIC HYBRIDIZATION OF 'CAIPIRA' SWEET ORANGE AND 'RANGPUR' LIME VIA PROTOPLAST FUSION}


'Caipira' sweet orange protoplasts were isolated from embryogenic suspension cultures and 'Rangpur' lime protoplasts were isolated from leaf mesophyl of "in vitro" seedlings. The enzime solution used for protoplast isolation was composed by $0.7 \mathrm{M}$ mannitol, 24.5mM CaCl $2,0.92 \mathrm{mM} \mathrm{NaH}_{2} \mathrm{PO}_{4}, 6.15 \mathrm{mM} \mathrm{MES}, 1 \%$ cellulase Onozuka RS, $1 \%$ macerase and $0.2 \%$ pectolyase Y-23. Protoplasts were purified by $25 \%$ sucrose $13 \%$ mannitol gradient on CPW culture media. Protoplast fusion was induced by chemical method, with $26.6 \mathrm{mM}$ polyetylene glycol (PEG) (MW=1450). Protoplasts were cultured in liquid medium. Microcalli were transfered to semi-solid EME mediun. Somatic embryogenesis was observed after 60 days of culture. Somatic embryos were germinated on semi-solid EME $+0.5 \mathrm{mg} \mathrm{l}^{-1} \mathrm{GA}_{3}$. Four out of 39 regenerated plants were confirmed as somatic hybrids by leaf morphological evaluation, chromossome counting and RAPD analyses.

\subsection{Introdução}

O Brasil é o maior produtor de citros do mundo (FAO, 1998). Entretanto, diversas pragas, doenças e outras limitações têm afetado o rendimento e a produção de frutos de qualidade das principais variedades cultivadas.

A dificuldade de obtenção de variedades superiores através de técnicas convencionais de melhoramento está relacionada a aspectos da biologia reprodutiva do gênero Citrus e seus parentais, tais como alta heterozigose, esterilidade de pólen e óvulo, incompatibilidade sexual, poliembrionia nucelar e juvenilidade (Grosser \& Gmitter Junior, 1990a; Ling et al., 1989; Vardi, 1981; Vardi \& Galun, 1989; Vardi et al., 1974; Vardi \& Spiegel-Roy, 1982) e herança quantitativa da maioria dos caracteres de interesse (Cameron \& Soost, 1976).

A produção de híbridos somáticos através da fusão de protoplastos é tecnologia que pode superar barreiras naturais a alopoliploidização dos citros e cria novas oportunidades, como a hibridação de espécies e de gêneros sexualmente incompatíveis, o que não seria possível através de hibridação natural ou convencional (Grosser \& 
Gmitter Junior, 1990a; Grosser et al., 1996b; Miranda et al., 1997; Vardi \& Galun, 1989).

Devido à hibridação somática ser um processo aditivo sem segregação, características que estão sob controle de gens dominantes ou co-dominantes em um dos parentais, têm uma boa probabilidade de serem expressos no híbrido somático, o que possibilita a produção de híbridos alotetraplóides com características complementares de ambos os parentais (Grosser \& Gmitter Junior, 1990a,b). Além disso, gens recessivos deletérios que são mascarados nos parentais devem permanecer mascarados e não serão expressos no híbrido somático (Gmitter Junior et al., 1992; Grosser \& Gmitter Junior, 1990a,b).

Em contraste com a hibridação sexual, onde a herança do genoma citoplasmático (cloroplastos e mitocôndrias) é predominantemente de origem materna, o híbrido somático recebe contribuições citoplasmáticas de ambos os parentais (Grosser et al. 1990b; Ohgawara \& Kobayashi, 1991).

O primeiro exemplo de híbrido somático de citros, obtido por Ohgawara et al. (1985), foi um alotetraplóide produzido pela fusão de protoplastos embriogênicos de laranja 'Trovita' (Citrus sinensis L. Osbeck) com protoplastos de folha de Poncirus trifoliata Rafinesque, espécies sexualmente compatíveis. A partir dessa data, um grande número híbridos somáticos de citros tem sido produzidos, incluindo vários entre pais sexualmente incompativeis. Atualmente mais de 100 híbridos somáticos de citros já foram relatados (Grosser et al., 1996b).

A estratégia da utilização da hibridação somática no melhoramento de portaenxertos de citros é a produção de híbridos somáticos poliplóides, que são de interesse por reduzir o tamanho da copa, o que diminui os custos de colheita, além da possibilidade de combinar características positivas complementares dos genótipos parentais (Grosser \& Gmitter Junior, 1990a).

Plantas poliplóides apresentam alterações morfológicas do fruto, como casca grossa, forma irregular e textura áspera (Gmitter Junior et al., 1992). Essas mudanças morfológicas associadas a poliploidia, podem ser toleradas em porta-enxertos, já que as 
mudanças não são expressas na copa enxertada nesse porta-enxerto (Grosser et al., 1996b), possibilitando a utilização direta desses híbridos somáticos como porta-enxertos.

Este trabalho relata a produção de um híbrido somático regenerado a partir de fusão química de protoplastos de laranja 'Caipira' (Citrus sinensis L. Osbeck) com limão 'Cravo' (Citrus limonia L. Osbeck), combinação essa a ser considerada como utilização futura em ensaios de porta-enxertos para citros.

\subsection{Material e Métodos}

\subsubsection{Material Vegetal}

Protoplastos foram isolados de suspensão celular embriogênica de laranja 'Caipira' (Citrus sinensis L. Osbeck) obtida de tecido nucelar e de mesófilo foliar de plântulas cultivadas "in vitro" de limão 'Cravo' (Citrus limonia L. Osbeck).

Calos embriogênicos de laranja 'Caipira' foram introduzidos em meio de cultura MT líquido (Murashige \& Tucker, 1969) modificado pela adição de $500 \mathrm{mg} \mathrm{l}^{-1}$ de extrato de malte, e mantidos sob agitação (100 rpm) no escuro, dando origem à cultura de células em suspensão.

As plântulas de limão 'Cravo' foram obtidas a partir de germinação "in vitro" de sementes maduras em meio de cultura RMAN (Grosser \& Gmitter Junior, 1990a). A germinação das sementes e desenvolvimento das plântulas se deram a $27 \mathrm{C}$, com fotoperíodo de 16 horas de luz.

\subsubsection{Isolamento de protoplastos}

Os isolamentos de protoplastos de suspensão celular embriogênica e de mesófilo foliar foram realizados com a metodologia de Mourão Filho (1995), que utiliza solução enzimática composta por manitol $(0,7 \mathrm{M}), \mathrm{CaCl}_{2}(24,5 \mathrm{mM}), \mathrm{NaH}_{2} \mathrm{PO}_{4}(0,92$ $\mathrm{mM})$, MES (6,15 mM), celulase (Onozuka R.S., 1\%), macerase (1\%) e pectoliase Y-23 $(0,2 \%)$, diluída em meio de cultura $\mathrm{BH}_{3}$. $\mathrm{O}$ isolamento dos protoplastos ocorreu em 14 horas de incubação, sob agitação de 40 rpm no escuro. 


\subsubsection{Purificação, fusão e plaqueamento dos protoplastos}

A purificação dos protoplastos foi feita através de passagem dos protoplastos por peneira de nylon de $50 \mu \mathrm{m}$, centrifugações a $100 \mathrm{~g}$ e gradiente sacarose $(25 \%)$ manitol (13\%), em meio de cultura CPW.

Os protoplastos de mesófilo foliar e suspensão celular purificados foram diluídos para a densidade de $2 \times 10^{5}$ protoplastos $\mathrm{ml}^{-1}$. Misturou-se igual volume de protoplastos de mesófilo foliar e suspensão celular embriogênica. Colocaram-se 2 gotas da mistura de protoplastos em placa de Petri descartável $58 \times 15 \mathrm{~mm}$. A fusão dos protoplastos foi feita por método químico, utilizando solução de $26,6 \mathrm{mM}$ de polietilenoglicol (PEG) (PM=1450). Após a fusão, foram feitas lavagens com meio de cultura $\mathrm{BH}_{3}$ 0,7M e os protoplastos foram plaqueados em meios de cultura líquidos $\mathrm{BH}_{3}$ $0,7 \mathrm{M}$ e EME 0,7M.

\subsubsection{Cultura dos protoplastos, indução à embriogênese e regeneração de plantas}

As primeiras divisões celulares foram obtidas aproximadamente 15 dias após a fusão. Após 20 dias da fusão, quando os protoplastos já tinham dado origem a microcolônias, foram adicionadas 10 a 12 gotas do meio de cultura 1:1:1 (v:v:v), composto por 1 parte de $\mathrm{BH}_{3} 0,6 \mathrm{M}, 1$ parte de $\mathrm{MT}$ líquido $0,6 \mathrm{M}$ e 1 parte de $0,145 \mathrm{M}$ (Murashige \& Tucker, 1969) modificados, com o objetivo de iniciar a redução do potencial osmótico do meio. Em subcultivos posteriores (a cada 20 a 30 dias), quando a cultura de protoplastos já estava mais vigorosa, formando microcalos, adicionou-se o meio de cultura $1: 2(\mathrm{v}: \mathrm{v})$, que é composto por 1 parte do meio de cultura $\mathrm{BH}_{3} 0,6 \mathrm{M}$ e 2 partes de MT 0,145M (Murashige \& Tucker, 1969) modificado.

Os microcalos originados foram transferidos para meio de cultura MT modificado para indução da embriogênese somática. Os microcalos deram origem a calos em aproximadamente um mês e o subcultivo foi realizado em intervalo de 4 semanas. Após aproximadamente 3 subcultivos, os calos deram origem a pequenos embriões. Os embriões foram isolados dos calos e transferidos para meio de cultura 
fresco a cada 3-4 semanas, para posterior desenvolvimento. A germinação ocorreu em meio MT modificado $+0,5 \mathrm{mg} \mathrm{l}^{-1}$ de $\mathrm{GA}_{3}$. As plântulas obtidas foram enraizadas em meio de cultura RMAN (Grosser \& Gmitter Junior, 1990).

\subsubsection{Aclimatização}

As plantas a serem adaptadas às condições ambiente ("ex vitro"), foram transferidas para vasos contendo vermiculita. Com o objetivo de manter a umidade relativa alta, as plântulas foram cobertas com saco plástico, que era retirado aproximadamente 5 vezes ao dia por 10 minutos. A freqüência e o tempo de retirada do saco plástico foram aumentados gradativamente com a finalidade de que as plântulas se adaptassem ao ambiente. $O$ processo de aclimatização teve duração de aproximadamente 1 mês. Após esse período, as plantas foram transferidas para vasos contendo mistura de $1: 1$ (v:v) de substrato comercial e terra corrigida e adubada e foram mantidas em telado. Foram aclimatizadas 4 plantas.

\subsubsection{Análise morfológica}

A análise morfológica foi feita por meio de comparação das características dos parentais laranja 'Caipira', limão 'Cravo' e da planta obtida de fusão de protoplastos desses dois parentais.

\subsubsection{Contagem do número de cromossomos}

A contagem do número de cromossomos de células meristemáticas de pontas de raízes mitoticamente ativas da planta regenerada foi feita de acordo com a metodologia de Vieira (1988). As pontas de raízes foram coletadas no início da manhã e em seguida colocadas em solução de 8 -hidroxiquinolina $0,002 \mathrm{M}$ por três horas a temperatura ambiente. Após esse tratamento, o material foi fixado em etanol acético (3:1) por cerca de dezoito horas e em seguida mantidos em álcool $70 \%$ por quatro horas. Para corar o 
material, foi feita hidrólise de oito minutos em $\mathrm{HCl} 1 \mathrm{~N} \mathrm{a} 60 \mathrm{C}$ e em seguida tratou-se com reativo de Schiff (fucsina-leuco-básica) por 45 minutos. Após lavagem em água corrente, as pontas de raiz foram esmagadas em carmim acético a $1 \%$ para o preparo das lâminas. As lamínulas foram removidas em ácido acético a $45 \%$. Após secagem ao ar, as lâminas foram montadas em Entellan e observadas em aumento de $1250 \mathrm{X}$. A confirmação da poliploidia se deu pela contagem de $2 n=4 x=36$ cromossomos em células das plantas analisadas.

\subsubsection{Análise de DNA através de marcadores moleculares tipo RAPD}

O DNA genômico das plantas híbridas e de seus parentais foi extraído a partir de folha, de acordo com a metodologia de Hoisington et al. (1994). Macerou-se 1 a 2 folhas em $\mathrm{N}_{2}$ líquido. Adicionou-se $500 \mu \mathrm{l}$ de $1 \mathrm{x}$ tampão de extração (Tris $\mathrm{pH}$ 7,5,

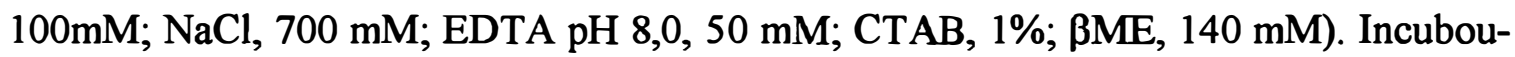
se o material em banho-maria a $65 \mathrm{C}$ por 60 minutos. Adicionou-se $500 \mu \mathrm{l}$ de clorofórmio-álcool isoamílico (CIA, 24:1) e extraiu-se por 5-10 minutos. Centrifugou-se por 10 minutos a $13000 \mathrm{rpm}$. O sobrenadante foi transferido para novo tubo e adicionouse $400 \mu \mathrm{l}$ de CIA 24:1. Extraiu-se por 5-10 minutos. Centrifugou-se por 10 minutos a $13000 \mathrm{rpm}$. O sobrenadante foi transferido para novo tubo. Foi feita 1 extração, adicionando-se $400 \mu \mathrm{l}$ de fenol. Centrifugou-se a $13000 \mathrm{rpm}$ por $10 \mathrm{~min}$. O sobrenadante foi transferido para novo tubo. Adicionou-se $400 \mu \mathrm{l}$ de etanol absoluto o material foi mantido em freezer por 10minutos. Centrifugou-se por 10 minutos a $13000 \mathrm{rpm}$. Lavouse o "pellet" em $400 \mu \mathrm{l}$ de etanol $75 \%$ por 10 minutos. Descartou-se o etanol e ressuspendeu-se o "pellet" em $480 \mu \mathrm{l}$ de TE-80. Adicionou-se $130 \mu \mathrm{l}$ de $\mathrm{NaCl} 5 \mathrm{M}$ e $1 \mathrm{ml}$ de etanol absoluto para a realização da reprecipitação. $O$ material foi mantido em freezer por 10 minutos. Centrifugou-se por 10 minutos a $13000 \mathrm{rpm}$. Descartou-se o líquido e lavou-se o DNA em solução de lavagem 1 por 10 minutos. Lavou-se o DNA em solução de lavagem 2. Drenou-se a solução e adicionou-se $50 \mu$ de TE 8.0 para ressuspender o DNA. 
Cada amostra utilizada para a realização da reação de amplificação de DNA (PCR) foi constituída de: Tris- $\mathrm{HCl} \mathrm{pH} \mathrm{9,0,} 100$ mM; KCl, 500 mM; 10x Buffer, $2.0 \mu \mathrm{l}$; $\mathrm{MgCl}_{2}, 2,5 \mathrm{mM}$; DNTPs, '100 $\mu \mathrm{M}$ de cada; Primer, 30 ng; Taq, 1 unidade; DNA, 30 ng, com volume total de $20 \mu \mathrm{l}$. As reações de PCR foram realizadas em termociclador (MJ Research, Watertow, MA) com o programa: 1) 93C por 2 minutos; 2) 92C por 1 minuto; 3) $37 \mathrm{C}$ por 1 minuto; 4) $72 \mathrm{C}$ por 2 minutos; 5) $72 \mathrm{C}$ por 5 minutos. Etapas 2 a 4 repetodas 43 ciclos.

Os primers utilizados foram : OPAA-3, OPAA-17, OPAA-18, OPAB-1, OPAB-5 e OPAB-7 (Tecnologia Operon). A análise do padrão de bandas de DNA foi realizada em gel horizontal de agarose (1,5\%) em solução Tampão TBE 0,5x (45 mM TRIS; $45 \mathrm{mM}$ ácido bórico; 1mM EDTA, pH 8,0), a temperatura ambiente. A eletroforese da reação de PCR foi conduzida à voltagem de $45 \mathrm{~V}$ ou corrente de $16 \mathrm{~mA}$ durante 4,5 horas. $\mathrm{O}$ gel foi corado com brometo de etídeo ( $10 \mu \mathrm{l}$ brometo : $100 \mathrm{ml}$ gel) e a visualização foi feita com a utilização de ultra-violeta.

\subsection{Resultados e Discussão}

Esse experimento de fusão teve como objetivo combinar características complementares dos parentais e produzir plantas com características superiores. A laranja 'Caipira' (Citrus sinensis L. Osbeck), como uma laranja doce caracteriza-se por induzir boa produção, frutos de qualidade, resistência ao declínio, mas é pouco tolerante à seca e à gomose (Pompeu Junior, 1991). O limão 'Cravo' (Citrus limonia L. Osbeck) é o porta-enxerto mais utilizado no Estado de São Paulo, devido às suas características agronômicas. Esse porta-enxerto é resistente à seca, produz frutos de boa qualidade, média resistência à gomose e como desvantagem é susceptível ao declínio (Pompeu Junior, 1991), que provavelmente deixa de ser problema quando utilizado em fusão de protoplastos com a laranja 'Caipira', que é resistente.

Protoplastos de laranja 'Caipira', isolados de cultura de células em suspensão, e de limão 'Cravo', isolados de mesófilo foliar, mostraram-se bastante adaptados ao

protocolo de isolamento e fusão utilizados. $\mathrm{O}$ processo de embriogênese somática se deu 
no meio de cultura MT (Murashige \& Tucker, 1969) modificado, como também foi citado por Grosser \& Gmitter Junior (1990a). A germinação dos embriões ocorreu na presença de ácido giberélico $\left(\mathrm{GA}_{3}\right)$, o que também foi observado em trabalhos de Ling et al., (1990) e Grosser \& Gmitter Junior, (1990a). A sequência das fases de isolamento de protoplastos até a planta aclimatizada pode ser vista na Figura 4.

De acordo com a análise morfológica dos parentais e da planta obtida de fusão de protoplastos (Figura 5), observou-se que a folha da planta híbrida apresenta, como esperado em uma planta tetraplóide, limbo foliar mais largo quando comparado aos parentais diplóides, são mais espessas devido ao aumento do nível de ploidia (tetraplóide, onde $2 n=4 x=36$ ), a coloração é mais escura e a asa do pecíolo é mais larga e fundida com a folha. Essas características são esperadas em plantas tetraplóides (Cameron \& Frost, 1968).

A análise citológica da planta obtida de fusão de protoplastos confirmou que se trata de um tetraplóide, com $2 \mathrm{n}=4 \mathrm{x}=36$ cromossomos. Nota-se que os cromossomos de citros são semelhantes entre si e de tamanho bastante reduzido, mesmo em aumentos de $1250 \times$ (Figura 6).

A confirmação definitiva da hibridação somática da planta regenerada a partir de fusão de protoplastos da combinação laranja 'Caipira' + limão 'Cravo' foi possível através da análise de marcadores moleculares (PCR-RAPD). Observando-se a Figura 7, é possível ver a contribuição de laranja 'Caipira' e de limão 'Cravo' no híbrido através de bandas polimórficas (específicas de cada parental) que encontram-se no padrão de bandas do híbrido e expressam a presença de sequências de DNA de ambos os parentais. Nos padrões de banda do primer OPAA3 é possível visualizar a presença de DNA de laranja 'Caipira' no híbrido pela presença de 1 banda polimórfica; o primer OPAA7 mostra a contribuição de limão 'Cravo' com 2 bandas polimórficas; o primer OPAA18 mostra 1 banda polimórfica de laranja 'Caipira' e 1 de limão 'Cravo'; o primer OPAB1 


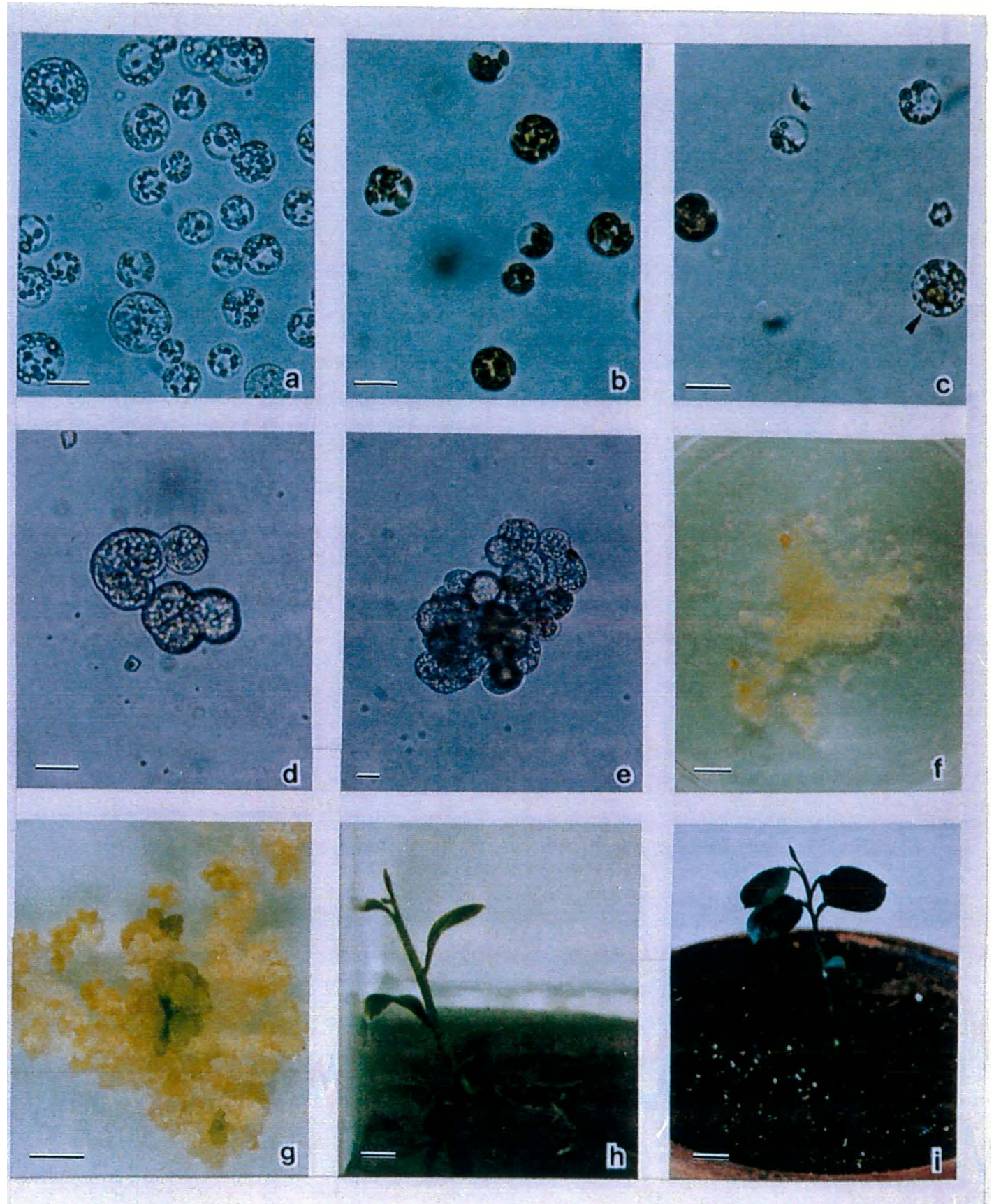

Figura 4 - Sequência das fases de isolamento de protoplastos até a planta aclimatizada. a. Protoplastos isolados de cultura de células embriogênicas em suspensão de laranja 'Caipira' (barra $=10 \mu \mathrm{m}$ ); b. protoplastos isolados de mesófilo foliar de limão 'Cravo (barra $=10 \mu \mathrm{m}$ ); c. fusão de protoplastos laranja 'Caipira' + limão 'Cravo' (barra $=10 \mu \mathrm{m})$; d. primeiras divisões de protoplastos de fusão $($ barra $=10 \mu \mathrm{m})$; e. microcolônias $($ barra $=10 \mu \mathrm{m}) ;$ f. microcalos $($ barra $=$ $5 \mathrm{~mm}$ ); g. embriões somáticos (barra $=0,5 \mathrm{~cm}$ ); h. plântula de laranja 'Caipira' + limão 'Cravo' em processo de enraizamento (barra $=0,5 \mathrm{~cm}$ ); i. plântula aclimatizada de laranja 'Caipira' + limão 'Cravo' (barra $=2,5 \mathrm{~cm})$. 

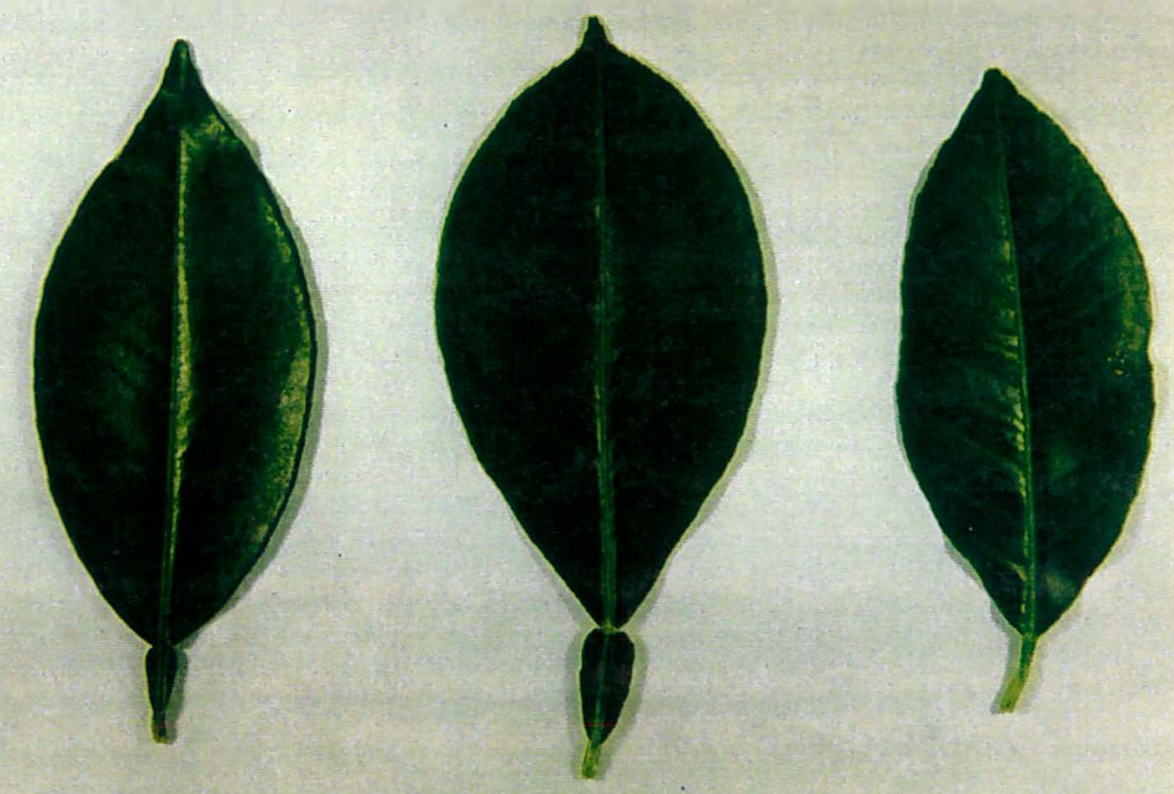

Figura 5 - Morfologia foliar de laranja 'Caipira' (esquerda), laranja 'Caipira' + limão ‘Cravo' (centro) e limão 'Cravo' (direita).

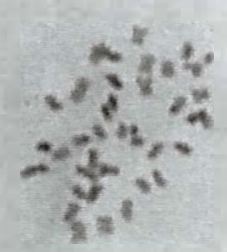

Figura 6 - Célula da plântula obtida de fusão de protoplastos contendo 36 cromossomos $($ Barra $=1 \mu \mathrm{m})$. 
mostra 5 bandas polimórficas caracterizando a contribuição de limão 'Cravo’ no híbrido; os primers OPAB5 e OPAB7 mostram a contribuição de laranja 'Caipira' com 1 banda polimórfica cada um.

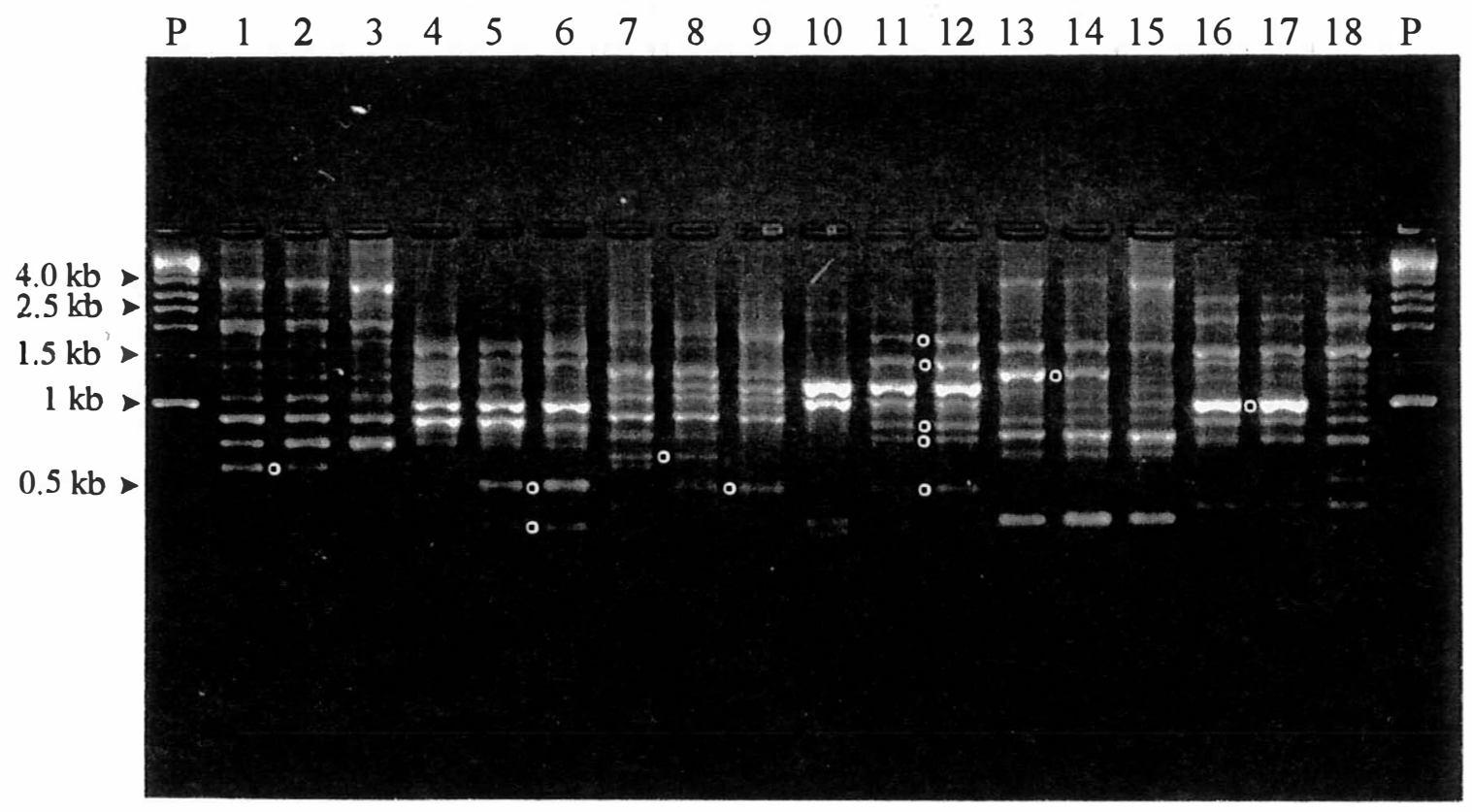

Figura 7 - Padrões de RAPD do híbrido somático e de seus parentais. Colunas 1 a $3=$ primer OPAA3, colunas 4 a $6=$ primer OPAA7, colunas 7 a $9=$ primer OPAA18, colunas 10 a $12=$ primer $\mathrm{OPAB} 1$, colunas 13 a $15=$ primer OPAB5 e colunas 16 a $18=$ primer OPAB7. Colunas $1,4,7,10,13$ e $16=$ laranja 'Caipira', colunas 2, 5, 8, 11, 14 e 17 = híbrido laranja 'Caipira' + limão 'Cravo', colunas 3, 6, 9, 12, 15 e 18 = limão 'Cravo'. P = Ladder $1 \mathrm{~Kb}$. Os pontos brancos indicam bandas que caracterizam a hibridação somática.

Dentre as 39 plantas regeneradas, 4 foram analisadas e são híbridos somáticos. Essas plantas serão levadas ao campo para futuras observações do comportamento como porta-enxerto das principais variedades cultivadas no Estado de São Paulo. 


\subsection{Conclusões}

De acordo com os resultados obtidos, pode-se concluir que:

1) O protocolo de isolamento, fusão e cultura de protoplastos utilizado foi eficiente para a regeneração do híbrido somático laranja 'Caipira' + limão 'Cravo'.

2) A confirmação da hibridação somática foi realizada com o conjunto de análises morfológica, citológica e moleculares. No referente à análise molecular, os primers OPAA3, OPAB5 e OPAB7 foram os mais adequados para indicação de polimorfismo em laranja 'Caipira', o primer OPAA18 mostrou contribuição de ambos os parentais e os primers OPAA7 e OPAB1 foram os mais indicados para mostrar a contribuição de limão ‘Cravo’.

3) O híbrido somático laranja 'Caipira' + limão 'Cravo' apresenta potencial para ser utilizado como porta-enxerto para citros. $\mathrm{O}$ híbrido aqui relatado deve ser tolerante à seca, apresentar resistência ao declínio, induzir boas produções e reduzir o tamanho das copas nele enxertadas. 


\section{CONCLUSÕES}

De acordo com os resultados obtidos nos trabalhos experimentais, pode-se concluir que:

1) Os meios de cultura utilizados no experimento de indução de calos embriogênicos mostraram-se bastante eficientes em seis dos sete cultivares introduzidos "in vitro". Alguns desses calos já foram utilizados em experimentos de fusão de protoplastos e juntamente com os calos de outros cultivares, poderão ser úteis em futuras manipulações biotecnológicas, como por exemplo, fusão de protoplastos.

2) Os meios de cultura EME e $e^{1 / 2}-\mathrm{EME}$ foram os mais eficientes em induzir a formação de calos embriogênicos em tecido nucelar na maioria dos cultivares introduzidos "in vitro".

3) O experimento para avaliação de diferentes fontes de carbono no estímulo à embriogênese somática de calos de fusão de protoplastos de citros mostrou a maltose como o açúcar mais eficiente, dentre os analisados, para as combinações testadas. Esse trabalho mostrou a importância da utilização do açúcar adequado à uma certa combinação de calos de fusão de protoplastos para a obtenção de maior eficiência em embriogênese somática, desenvolvimento de embriões e regeneração de plantas.

4) Os ensaios de fusão de protoplastos que resultaram na regeneração do híbrido somático laranja 'Caipira' + limão 'Cravo' contribuíram para o desenvolvimento e adaptação de protocolos de hibridação somática entre variedades economicamente importantes para a citricultura paulista.

5) O híbrido somático laranja 'Caipira' + limão 'Cravo' deve apresentar características complementares aos dois parentais e deve ser incluído em ensaios para avaliação de porta-enxertos para a citricultura paulista. 


\section{ANEXO}

Composição dos meios de cultura:

1. Solução estoque de macronutrientes de MT (50x) g/litro $\mathrm{NH}_{4} \mathrm{NO}_{3}$

$\mathrm{KNO}_{3}$

95.0

$\mathrm{MgSO}_{4} * 7 \mathrm{H}_{2} \mathrm{O}$

18.5

$\mathrm{KH}_{2} \mathrm{PO}_{4}$ (monobásico)

7.5

$\mathrm{K}_{2} \mathrm{HPO}_{4}$ (dibásico)

1.0

2. Solução estoque de micronutrientes de MT (100x) g/litro

$\mathrm{H}_{3} \mathrm{BO}_{3}$

$\mathrm{MnSO}_{4} * \mathrm{H}_{2} \mathrm{O}$

0.62

$\mathrm{ZnSO}_{4} * 7 \mathrm{H}_{2} \mathrm{O}$

1.68

0.86

$\mathrm{KI}$

0.083

$\mathrm{Na}_{2} \mathrm{MoO} 4 * 2 \mathrm{H}_{2} \mathrm{O}$

0.025

$\mathrm{CuSO}_{4} * 5 \mathrm{H}_{2} \mathrm{O}$

0.0025

$\mathrm{CoCl}_{2} * 6 \mathrm{H}_{2} \mathrm{O}$

0.0025

3. Solução estoque de ferro de MT (200x)

$\mathrm{Na}_{2} \mathrm{EDTA}$

g/litro

7.45

$\mathrm{FeSO}_{4} * 7 \mathrm{H}_{2} \mathrm{O}$

5.57

4. Solução estoque de vitaminas de MT (100x)

g/litro

inositol

10.0

thiamina-HCl

1.0

piridoxina

1.0

ácido nicotínico

0.5

glicina

0.2

5. Solução estoque de cálcio (66x) g/litro

$\mathrm{CaCl}_{2} * 2 \mathrm{H}_{2} \mathrm{O}$

29.33

6. Solução estoque de macronutrientes de $\mathrm{BH}_{3}(100 \mathrm{x})$ $\mathrm{MgSO}_{4}$

g / litro

$\mathrm{KH}_{2} \mathrm{PO}_{4}$ (monobásico)

37

$\mathrm{K}_{2} \mathrm{HPO}_{4}$ (dibásico)

15

$\mathrm{KCl}$

2 
7. Solução estoque A de multivitaminas de $\mathrm{BH}_{3}(100 \mathrm{x})$ Pantotenato de cálcio

$\mathrm{g} / 100 \mathrm{ml}$ Ácido ascórbico

Cloreto de colina

0.1

Ácido p-Aminobenzóico

0.05

Ácido fólico

0.001

Riboflavina

0.02

0.01

Biotina

0.001

8. Solução estoque $\mathrm{B}$ de multivitaminas de $\mathrm{BH}_{3}(100 \mathrm{x})$ Retinol (vitamina A)*

$\mathrm{g} / 100 \mathrm{ml}$

0.001

0.001

Cholecalciferol (vitamina $\left.\mathrm{D}_{3}\right)^{*}$

0.002

* insolúvel em água, solúvel em ETOH

9. Solução estoque de $\mathrm{KI}$ de $\mathrm{BH}_{3}(100 \mathrm{x})$

KI

$\mathrm{g} / 100 \mathrm{ml}$

0.075

10. Solução estoque de ácidos orgânicos de $\mathrm{BH}_{3}(50$ x)

Piruvato de sódio

$\mathrm{g} / 100 \mathrm{ml}$

0.1

Ácido cítrico

0.2

Ácido málico

0.2

Ácido fumárico

0.2

11. Solução estoque de açúcares de $\mathrm{BH}_{3}(100 \mathrm{x})$

$\mathrm{g} / 100 \mathrm{ml}$

Frutose

2.5

Ribose

2.5

Xilose

2.5

Manose

2.5

Ramose

2.5

Celobiose

2.5

Galactose

2.5

Manitol

12. Solução estoque 1 de sais de CPW

$\mathrm{KH}_{2} \mathrm{PO}_{4}$

$\mathrm{KNO}_{3}$

$0,2720 \mathrm{~g} / 100 \mathrm{ml}$

$\mathrm{MgSO}_{4}$

$1,0000 \mathrm{~g} / 100 \mathrm{ml}$

$2,5000 \mathrm{~g} / 100 \mathrm{ml}$

$\mathrm{KI}$

$\mathrm{CuSO}_{4}$

$0,0016 \mathrm{~g} / 100 \mathrm{ml}$

$0,000025 \mathrm{~g} / 100 \mathrm{ml}$

13. Solução estoque 2 de sais de CPW

$\mathrm{CaCl}_{2}$

$1,5 \mathrm{~g} / 100 \mathrm{ml}$ 


\section{Meios de cultura}

\section{EME (0.145M)}

Estoque de macronutrientes de MT (50x) $20 \mathrm{ml} / 1$

Estoque de micronutrientes de MT (100x) $10 \mathrm{ml} / \mathrm{l}$

Estoque de vitaminas de MT (100x) $10 \mathrm{ml} / \mathrm{l}$

Estoque de cálcio de MT (66x) $15 \mathrm{ml} / 1$

Estoque de ferro de MT (200x) $5 \mathrm{ml} / 1$

Sacarose $\quad 50 \mathrm{~g} / 1$

Extrato de malte $\quad 0.5 \mathrm{~g} / 1$

Ágar

$8.0 \mathrm{~g} / 1$

Ajustar o $\mathrm{pH}$ para $5.8 \mathrm{com} \mathrm{KOH}$

No experimento de efeito de diferentes fontes de carbono no estímulo à embriogênese somática, substituiu-se a sacarose do meio de cultura pelos outros açúcares.

\section{2. $1 / 2$-EME}

Estoque de macronutrientes de MT (50 x) $20 \mathrm{ml} / \mathrm{l}$

Estoque de micronutrientes de MT (100 x) $10 \mathrm{ml} / \mathrm{l}$

Estoque de vitaminas de MT (100 x) $10 \mathrm{ml} / \mathrm{l}$

Estoque de cálcio de MT (66x) $15 \mathrm{ml} / \mathrm{l}$

Estoque de ferro de MT (200x) $5 \mathrm{ml} / 1$

Sacarose $\quad 50 \mathrm{~g} / \mathrm{l}$

Extrato de malte $\quad 1.5 \mathrm{~g} / 1$

Ágar

Ajustar o $\mathrm{pH}$ para $5.8 \mathrm{com} \mathrm{KOH}$

\section{Meio de cultura CPW}

Adicionar $1 \mathrm{ml}$ de cada estoque / $100 \mathrm{ml}$ de meio de cultura

Ajustar o $\mathrm{pH}$ para 5,8 com $\mathrm{KOH}$

Para CPW com $13 \%$ de manitol, adicionar $13 \mathrm{~g}$ de manitol / $100 \mathrm{ml}$

Para CPW com $25 \%$ de sacarose, adicionar $25 \mathrm{~g}$ de sacarose / $100 \mathrm{ml}$

\section{Solução enzimática}

Manitol (0,7 M)

$\mathrm{CaCl}_{2}(24,5 \mathrm{mM})$

$\mathrm{NaH}_{2} \mathrm{PO}_{4}(0,92 \mathrm{mM})$

M.E.S. $(6,15 \mathrm{mM})$

$1 \%$ de celulase (Onozuka R.S.)

$1 \%$ de macerase

$0,2 \%$ de pectoliase $\mathrm{Y}-23$

Ajustar pH para 5,6 com $\mathrm{KOH}$

Esterilizar em filtro de $0,2 \mu$
$5,12 \mathrm{~g} / 40 \mathrm{ml}$

$0,144 \mathrm{~g} / 40 \mathrm{ml}$

$0,0044 \mathrm{~g} / 40 \mathrm{ml}$

$0,048 \mathrm{~g} / 40 \mathrm{ml}$

$0,4 \mathrm{~g} / 40 \mathrm{ml}$

$0,4 \mathrm{~g} / 40 \mathrm{ml}$

$0,08 \mathrm{~g} / 40 \mathrm{ml}$ 
5. Meio de cultura de $\mathrm{BH}_{3}(0,6 \mathrm{M})$

Estoque de macronutrientes de $\mathrm{BH}_{3}(100 \mathrm{x}) \quad 10 \mathrm{ml} / \mathrm{l}$

Estoque de Micronutrientes de MT (100 x) $10 \mathrm{ml} / \mathrm{l}$

Estoque de Vitamina de MT (100 x) $10 \mathrm{ml} / 1$

Estoque de cálcio de MT (66x) $\quad 15 \mathrm{ml} / 1$

Estoque de ferro de MT $(200 \mathrm{x}) \quad 5 \mathrm{ml} / 1$

Estoque A de multivitaminas de $\mathrm{BH}_{3}(100 \mathrm{x}) \quad 2 \mathrm{ml} / \mathrm{l}$

Estoque B de multivitaminas de $\mathrm{BH}_{3}(100 \mathrm{x}) \quad 1 \mathrm{ml} / 1$

Estoque de $\mathrm{KI}$ de $\mathrm{BH}_{3}(100 \mathrm{x}) \quad 1 \mathrm{ml} / \mathrm{l}$

Estoque de açúcares de $\mathrm{BH}_{3}(100 \mathrm{x}) \quad 10 \mathrm{ml} / \mathrm{l}$

Estoque de ácidos orgânicos (50 x) $20 \mathrm{ml} / \mathrm{l}$

Água de coco $20 \mathrm{ml} / 1$

Extrato de malte $1 \mathrm{~g} / 1$

Sacarose* $\quad 51,35 \mathrm{~g} / 1$

Manitol $\quad 81,99 \mathrm{~g} / 1$

Glutamina $\quad 3,1 \mathrm{~g} / 1$

Caseína hidrolisada $\quad 0,25 \mathrm{~g} / 1$

Para $\mathrm{BH}_{3}$ 0,7 M, adicionar 85,56 g/l de sacarose e para $\mathrm{BH}_{3} 0,8 \mathrm{M}$, adicionar $119,80 \mathrm{~g} / \mathrm{l}$ de sacarose

\section{Solução de PEG}

Polietilenoglicol $(\mathrm{PM}=1450)$

$\mathrm{CaCl}_{2} \cdot 2 \mathrm{H}_{2} \mathrm{O}$

$40 \mathrm{~g} / 1$

Glucose

$0,97 \mathrm{~g} / 1$

Ajustar o pH para 6,0 com $\mathrm{KOH}$

Esterilizar em filtro de $0,2 \mu$

7. Meios de cultura para redução osmótica de protoplastos
a) 1-1-1
1 parte de $\mathrm{BH}_{3} 0,6 \mathrm{M}$
1 parte de EME 0,6 M
1 parte de EME regular $(0,146 \mathrm{M})$
Ajustar o $\mathrm{pH}$ para 5,7

\section{b) 1-2}

1 parte de $\mathrm{BH}_{3} 0,6 \mathrm{M}$

2 partes de EME regular $(0,146 \mathrm{M})$

Ajustar o $\mathrm{pH}$ para 5,7 
8. RMAN (meio de enraizamento)

Estoque de macronutrientes de MT (50 x)

$10 \mathrm{ml} / 1$

Estoque de micronutrientes de MT (100 x)

$5 \mathrm{ml} / \mathrm{l}$

Estoque de vitaminas de MT (100 x)

$5 \mathrm{ml} / 1$

Estoque de cálcio de MT (66 x)

$15 \mathrm{ml} / 1$

Estoque de ferro de MT (200 x)

$5 \mathrm{ml} / \mathrm{l}$

Estoque de NAA (279.3 mg/l)

$72 \mu \mathrm{l} / 1$

Carvão ativado

$0.5 \mathrm{~g} / 1$

Sacarose

$25 \mathrm{~g} / 1$

Ágar

$8 \mathrm{~g} / 1$ 


\section{REFERÊNCIAS BIBLIOGRÁFICAS}

ANKER, L. Auxin synthesis by sugars, notably by galactose. Acta Botanica Neerlandica, v.23, p.705-714, 1974.

BARRET, H. C.; RHODES, A. M. A numerical taxonomic study of affinity relationships in cultivated Citrus its close relatives. Systematic Botany, v.1, n.2, p.105-136, 1976.

BENGOCHEA, T.; DODDS, J. H. A plant protoplast: a biotechnological tool for plant improvement. Cambridge: Chapman \& Hall, 1986. 90p.

BRIEGER, F. G.; MOREIRA, S. Experiências de cavalos para citrus II. Bragantia, v.5, n. 10, p.597-658, out. 1945.

BUTTON, J. The effect of some carbohydrates on the growth and organization of Citrus ovular callus. Zeitschrift für Pfanzenphysiologie, v.88, p.61-68, 1978.

CABASSON, C.; OLLITRAULT, P.; CÔTE, F-X.; FERRIÈRE, N-M.; DAMBIER, D.; DALNIC, R.; TEISSON, C. Characteristics of Citrus cell cultures during undifferentiated growth on sucrose and somatic embryogenesis on galactose. Physiologia Plantarum, v.93, p.464-470, 1995. 
CAMERON, J. W.; FROST, H. B. Genetics, breeding and nucellar embryony. In: REUTHER, W.; BATCHELOR, L. D.; WEBBER, H. J. (Ed.). The citrus industry. Berkley: University of California, 1968. v.2, p.325-370.

CAMERON, J. W.; SOOST, R. K. Citrus. In: SIMMONDS, N. W. (Ed.) Evolution of crop plants. London: Longman, 1976. p.261-265.

CASTLE, W. S. Citrus rootstocks. In: ROM, R. C.; CARLSON, R. F. (Ed.) Rootstocks for fruit crops. New York: John Wiley, 1987. p.361-399.

CHAPOT, H. The citrus plant. In: CIBA-GEIGY Agrochemicals technical monograph. Citrus. 1975.88 p. (n.4).

DAVIES, F.; ALBRIGO, L. Citrus. Wallingford:-CAB International,1994. cap.2, p.12-51: Taxonomy, cultivars and breeding.

FAO. FAOSTAT - Statistics Database. http://apps.fao.org. (15 Jun. 1998).

FIGUEIREDO, J. O. de. Variedades copa de valor comercial. In: RODRIGUEZ, O; VIÉGAS, F.; POMPEU JUNIOR, J.; AMARO, A. S. Citricultura brasileira. Campinas: Fundação Cargill, 1991. p.228-264.

FIGUEIREDO, J. O. de; POMPEU JUNIOR, J.; RODRIGUEZ, O.; VEIGA, A. A.; ABRAMIDES, E. Competição de dez porta-enxertos para a tangerina-Poncã (Citrus reticulata Blanco) In: CONGRESSO BRASILEIRO DE FRUTICULTURA, 2., Viçosa, 1973. Anais. Viçosa: Sociedade Brasileira de Fruticultura, 1973. p.127-147.

FIGUEIREDO, J. O. de; POMPEU JUNIOR, J.; PIO, R. M.; TEÓFILO SOBRINHO, J.; DOMINGUES, E. T.; LARANJEIRA, F. F. Produção inicial do tangor 'Murcote' sobre dezesseis porta-enxertos em São Paulo. Laranja, v.18, n. 1, p.165-173, 1997. 
FIGUEIREDO, J. O. de; POMPEU JÚNIOR., J.; TEÓFILO, J.; REIS, A. J.; MARTINS, A. L. M.; HIROCE, R.; IGUE, T. Competição de 16 porta-enxertos para o limoeiro 'Siciliano' Citrus limon L. Burm F., clone necelar. In: CONGRESSO BRASILEIRO DE FRUTICULTURA, 8., Brasília, 1986. Anais. Brasília: Sociedade Brasileira de Fruticultura, 1986. p.133-139.

GLEDDIE, S. C. Protoplasts and transformation procedures. In: GAMBORG, O. L.; PHILLIPS, G. C. (Ed.) Plant cell tissue and organ culture: fundamental methods. Berlin: Springer-Verlag, 1995. cap.14, p.167-180.

GMITTER JUNIOR., F. G.; GROSSER J. W.; MOORE, G. A. Citrus. In: HAMMERSCHLAG, F. A. ; LITZ, R. E. (Ed.) Biotechnology of perenial fruit crops. Cambridge: University Press, 1992. cap.14, p.335-369.

GMITTER JUNIOR, F. G.; LING, X. B.; DENG, X. X. Induction of triploid Citrus plants from endosperm calli in vitro. Theoretical and Applied Genetics, v.80, p.785-790, 1990.

GROSSER, J. W. Citrus scion and rootstocks improvement via somatic hybridization. Acta Horticulturae, v.336, p.297-305, 1993.

GROSSER, J. W. In vitro culture of ropical fruits. In: VASIL, I. K.; THORPE, T. A. (Ed.) Plant cell and tissue culture. Dordrecht: Kluwer Academic, 1994. cap.19, p.475-496.

GROSSER, J. W. \& GMITTER JUNIOR., F. G. Protoplast fusion and citrus improvement. Plant Breeding Reviews, v.8, p.339-374, 1990a. 
GROSSER, J. W. \& GMITTER JUNIOR., F. G. Somatic hybridization of Citrus with wild relatives for germplasm enhancement and cultivar development. HortScience, v.25, n.2, p.147-151, Feb. 1990b.

GROSSER, J. W.; GMITTER JUNIOR, F. G.; LOUZADA, E. S.; CHANDLER, J. L. Production of somatic hybrid and autotetraploid breeding parents for seedless citrus development. HotScience, v.27, n. 10, p.1125-1127, 1992.

GROSSER, J. W.; GMITTER JUNIOR, F. G.; TUSA, N.; REFORGIATO RECUPERO, G.; CUCINOTTA, P. Further evidence of a cybridization requirement for plant regeneration from citrus leaf protoplasts following somatic fusion. Plant Cell Reports, v.15, p.672-676, 1996a.

GROSSER, J. W.; MOURÃO FILHO, F. A. A.; GMITTER JUNIOR, F. G.; LOUZADA, E. S.; JIANG, J.; BAERGEN, K.; QUIROS, A.; CABASSON, C.; SCHELL, J. L.; CHANDLER, J. L. Allotetraploid hybrids between Citrus and seven related genera produced by somatic hybridization. Theoretical and Applied Genetics, v.92, p.557-582, 1996 b.

HARTMANN, H. T.; KESTER, D. E.; DAVIES JUNIOR, F. T. Plant propagation principles and practices. 5.ed. Englewood Cliffs: Prentice Hall, 1990. cap.8, p.165198: Source selection and management in vegetative propagation.

HIDAKA, T.; KAIIURA, I. Plantlet differentiation from callus protoplasts induced from Citrus embryo. Scientia Horticulturae, v.34, p.85-92, 1988.

HIDAKA, T.; OMURA, M.; UGAKI, M.; TOMIYAMA, M; MOTOYOSHI, F. Agrobacterium-mediated transformation in Citrus. In: INTERNATIONAL HORTICULTURAL CONGRESS, 23., Firenze, 1990. Abstracts, Firenze, 1990a. p. 135 . 
HIDAKA, T.; OMURA, M.; UGAKI, M.; TOMIYAMA, M.; KATO, A.; OHSHIMA, M.; MOTOYOSHI, F. Agrobacterium-mediated transformation and regeneration of Citrus spp from suspension cells. Japanese Journal of Breeding, v.40, p.199-207, 1990b.

HODGSON, R. W. Horticultural varieties of citrus. In: REUTHER, W.; WEBBER, H. J.; BATCHELOR, L. D. (Ed.) The citrus industry. Berkeley: University of California, 1967. v.1, p.431-591.

HOISINGTON, D.; KHAIRALLAH， M.; GONZÁLEZ-DE-LEÓN. Laboratory Protocols: CIMMYT Applied Molecular Genetics Laboratory. 2.ed. Mexico: CIMMYT. 1994, 88p.

JIMÉNEZ, V. M. El cultivo de protoplastos en cítricos y su potencial para el mejoramiento genético. Agronomía Costarricense, v.20, n.2, p.187-204, 1996.

JUMIN, H. B.; NITO, N. Plant regeneration via embryogenesis from protoplasts of six plant species related to Citrus. Plant Cell Reports, v.15, p.332-336, 1996 a.

JUMIN, H. B.; NITO, N. Plant regeneration via somatic embryogenesis from protoplasts of Uganda cherry orange (Citropsis schweinfurthii). Plant Cell Reports, v.15, p.754-757, 1996b.

KANEYOSHI, J.; KOBAYASHI, S,; NAKAMURA, Y.; SHIGEMOTO, N.; DOI, Y. A simple and efficient gene trnafer system of trifoliate orange (Poncirus trifoliata Raf.) Plant Cell Reports, v.13, p.541-545, 1994.

KOBAYASHI, S. Uniformity of plants regenerated from orange (Citrus sinensis Osb.) protoplasts. Theoretical and Applied Genetics, v.74, p.10-14, 1987. 
KOBAYASHI, S.; OHGAWARA, T. Production of somatic hybrid plants throgh protoplast fusion in citrus. Japan Agricultural Research Quarterly, v.22, n.3, p.181-188, 1988.

KOBAYASHI, S.; UCHIMIYA, H. Expression and integration of a forein gene in orange (Citrus sinensis Osb.) protoplasts by direct DNA transfer. Japanese Journal of Genetics, v.64, p.91-97, 1989.

KOCHBA, J.; SPIEGEL-ROY, P. The effects of auxins, cytokinins and inhibitors on embryogenesis in habituated ovular callus of the "Shamouti" orange (Citrus sinensis). Zeitschrift für Pflanzenphysiologie, v.81, p.283-288, 1977.

KOCHBA, J.; SPIEGEL-ROY, P.; SAFRAN, H. Adventive plants from ovules and nucelli in Citrus. Planta, v. 106, p.237-245; 1972.

KOCHBA, J.; SPIEGEL-ROY, P.; NEUMANN, H.; SAAD, S. Effect of carboydrates on somatic embryogenesis un subcultures nucellar callus os Citrus cultivars. Zeitschrift für Pflanzenphysiologie, v. 105, p. 359-368, 1982.

KOCHBA, J.; SPIEGEL-ROY, P.; SAAD, S.; NEUMANN, H. Stimulation of embryogenesis in Citrus tissue culture by galatose. Naturwissenschaften, v.65, p. 261-262, 1978.

KOLLER, O. C. Citricultura: laranja, limão e tangerina. Porto Alegre: Rígel, 1994, cap.5, p.49-62: Melhoramento e cultivares.

KUNITAKE, H.; MII, M. Somatic embryogenesis in Citrus species. In: BAJAJ, Y. P. S. (Ed.) Somatic embryogenesis and syntetic seed I. Berlin: Springer-Verlag, 1995. cap.3.4, p.280-298: (Biotechnology in Agriculture and Forestry, 30). 
KUNITAKE, H.; KAGAMI, H.; MII, M. Somatic embryogenesis and plant regeneration from protoplasts of 'Satsuma' mandarin (Citrus unshiu Marc.). Scientia Horticulturae, v.47, p.27-33, 1991.

LATADO, R. R. Hibridação somática entre limão Cravo (Citrus limonia Osbeck) e tangerina Cleópatra (Citrus reshni Hort.). Piracicaba, 1998. 146p. Tese (Doutorado) - Escola Superior de Agricultura "Luiz de Queiroz", Universidade de São Paulo.

LING, J-T.; IWAMASA, M. Plant regeneration from embryogenic calli of six Citrus related genera. Plant Cell, Tissue and Organ Culture, v.49, p.145-148, 1997.

LING, J-T; NITO, N.; IWAMASA, M. Plant regeneration from protoplasts of Calamondin (Citrus madurensis Lour.). Scientia Horticulturae, v.39, p.325-333, 1989.

LING, J-T; NITO, N.; IWAMASA, M.; KUNITAKE, H. Plant regeneration from protoplast isolated from embriogenic callus of Satsuma. HortScience, v.25, n.8, p.970-972, 1990.

LOUZADA, E. S. Possibilidades do uso da biotecnologia em citros. Laranja, v.11, n.1, p.151-165, 1990.

LOUZADA, E. S.; GROSSER, J. W.; GMITTER JUNIOR, F. G.; NIELSEN, B.; CHANDLER, J. L. Eight new somatic hybrid citrus rootstocks with potencial for improved disease resistance. HortScience, v.27, n.9, p.1033-1036, 1992.

MERKLE, S. A.; PARROTT, W. A.; FLINN, B. S. Morphogenic aspects of somatic embryogenesis. In: THORPE, T. A. (Ed). In vitro embryogenesis in plants. Dordrecht: Kluwer Academic, 1995. p.155-203. 
MIRANDA, M.; MOTOMURA, T.; IKEDA, F.; OHGAWARA, T.; SAITO, W.; ENDO, T.; OMURA, M.; MORIGUCHI, T. Somatic hybrids obtained by fusion between Poncirus trifoliata (2x) and Fortunella hindsii (4x) protoplasts. Plant Cell Reports, v.16, p.401-405, 1997.

MOORE, G. A.; JACONO, C. C.; NEIDIGH, J. L.; LAWRENCE, S. D.; CLINE, K. Agrobacterium-mediated transformation of Citrus stem segments and regeneration of transgenic plants. Plant Cell Reports, v.11, p.238-242, 1992.

MOORE, G. A.; JACONO, C. C.; NEIDIGH, J. L.; LAWRENCE, S. D.; CLINE, K. Transformation in Citrus. In: BAJAJ, Y. P. S. (Ed.) Plant protoplasts and genetics Engeneering IV. Berlin: Springer-Verlag, 1993. p. 194-208. (Biotechnology in Agriculture and Forestry, 23).

MOREIRA, C. S.; PIO, R. M. Melhoramento de citros. In: RODRIGUEZ, O.; VIÉGAS, F.; POMPEU JUNIOR, J.; AMARO, A. S. Citricultura Brasileira. Campinas: Fundação Cargil, 1991. p.116-152.

MOREIRA, S. Experiências de cavalos para citrus I. Bragantia, v.1, n.8/9, 525-544, ago. set. 1941 .

MOREIRA, S. Cavalos para citricultura em São Paulo. Revista de Agricultura, v.21, n.5/6, p.206-226, 1946 .

MOREIRA, S.; SALIBE, A. A.; OLIVEIRA, V. G.; ABRAMIDES, E. Experimentos de cavalos para citros V. Ciência e Cultura, v.17, n.2, p.190-191, 1965.

MOTOMURA, T.; HIDAKA, T.; MORIGUCHI, T.; AKIHAMA, T.; OMURA, M. Intergeneric somatic hybrids between Citrus and Atalantia or Severinia by eletrofusion, and recombination of mitochondrial genomes. Breeding Science, v.45, p.309-314, 1995. 
MOURÃO FILHO, F. A. A. Protoplast fusion of citrus for rootstocks and scion improvement with emphasis on wide hybridization. Gainesville, Estados Unidos, 1995. 152p. Thesis (Ph.D) - University of Florida.

MOURÃO FILHO, F. A. A.; GROSSER, J. W. Callus induction from Citrus relatives: an alternative source of protoplasts for somatic hybridization experiments. Proceedings of Florida State Horticultural Society, v.105, p.52-56, 1992.

MOURÃO FILHO, F. A. A.; GMITTER JUNIOR, F. G.; GROSSER, J. W. New tetraploid breeding parents for triploid seedless citrus cultivar development. Fruit Varieties Journal, v.50, n.2, p.76-80, 1996.

MÜLLER, G. W.; TEÓFILO SOBRINHO, J; DOMINGUES, E. T. Compatibilidade da laranjeira 'Pera' clone Bianchi, sobre doze porta-enxertos após 23 anos de plantio. Laranja, v.17, n. 1, p.123-141, 1996.

MURASHIGE, T.; TUCKER, D. P. H. Growth factor requirements of citrus tissue culture. In: FIRST CITRUS SYMPOSIYM, 1., Riverside, 1969. Proceedings of First Citrus Symposiym. Riverside: University of California, 1969. p.1155-1161.

OHGAWARA, T.; KOBAYASHI, S. Aplication of protoplast fusion to citrus breeding. Food Biotechnology, v.5, n.2, p.169-184, 1991.

OHGAWARA, T.; UCHIMIYA, H.; ISHII, S.; KOBAYASHI, S. Somatic hybridization between Citrus sinensis and Poncirus trifoliata. In: BAJAJ, Y. P. S. (Ed.) Somatic hybridization in crop improvement I. Berlin: Springer-Verlag, 1994. cap.6.2, p. 439-454. (Biotechnology in Agriculture and Forestry, 27). 
OHGAWARA, T.; KOBAYASHI, S.; OHGAWARA, E.; UCHIMIYA, H.; ISHI, S. Somatic hybrid plants obtained by protoplast fusion between Citrus sinensis and Poncirus trifoliata. Theoretical and Applied Genetics, v.71, p.1-4, 1985.

OLIVEIRA, R. P.; MENDES, B. M. J.; TULMANN NETO, A. Obtenção e cultura de calos nucelares de limão Cravo, tangerina Cleópatra e Poncirus trifoliata. Revista Brasileira de Fisiologia Vegetal, v.6, n.2, p.115-119, 1994.

POMPEU JUNIOR, J. Porta-enxertos. In: RODRIGUEZ, O.; VIÉGAS, F.; POMPEU Jr., J.; AMARO, A. A. Citricultura brasileira. 2.ed. Campinas: Fundação Cargill, 1991. v.1, 265-280.

POMPEU JUNIOR, J.; FIGUEIREDO, J. O.; TEÓFILO SOBRINHO, J.; JORGE, J. P. N.; JACON, J. R. Competição de clones de limão 'Cravo' e de limão 'Volkameriano' como porta-enxertos para laranja 'Natal'. In: CONGRESSO BRASILEIRO DE FRUTICULTURA, 8., Brasília, 1986. Anais. Brasília: Sociedade Brasileira de Fruticultura, 1986. p.147-151.

POMPEU JUNIOR, J.; FIGUEIREDO, J. O.; RODRIGUEZ, O.; ALOISI SOBRINHO, J.; IGUE, T.;SALIBE, A. A. Comportamento da laranjeira Valência em 18 portaenxertos. In: CONGRESSO BRASILEIRO DE FRUTICULTURA, 6., Recife, 1981. Anais. Recife: Sociedade Brasileira de Fruticultura, 1981. p.530-541.

SAITO, W.; OHGAWSRA, T.; SHIMIZU, J.; ISHII, S. Acid citrus somatic hybrids between sudachi (Citrus sudachi Hort. ex Shirai) and lime (C. aurantifolia Swing.) produced by eletrofusion. Plant Science, v.77, p.125-130, 1991.

SAUNT, J. Citrus varieties of the world. Norwich: Sinclair International Limited, 1990. $126 \mathrm{p}$. 
SCORA, R. W. On the theory and origen of citrus. Bulletin of the torrey botanical club, v.102, n.6, p.369-375, Nov./Dec. 1975.

SCORA, R. W.; KUMAMOTO, J.; SOOST, R. K.; NAUER, E. M. Contribution to the origen of the grapefruit, Citrus paradisi (Rutaceae). Systematic Botany, v.7, n.2, p.170-177, 1982.

SINGH, A. K.; NITO, N.; IWAMASA, M. Influence of lactose and glycerol on growth and somatic embryogenesis of citrus callus. Acta Horticulturae, v.321, p.606-609, 1992.

SOOST, R. K.; CAMERON, J. W. Citrus. In: JANICK, J.; MOORE, J. N. (Ed.) Advances in fruit breeding. West Lafayette: Purdue University Press, 1975. p.507540.

SPIEGEL-ROY, P.; VARDI, A. Citrus. In: AMIRATO, P. V.; EVANS, D. A.; SHARP, W. R.; YAMADA, Y. (Ed.) Handbook of plant cell culture. New York: Macmillan Co., 1984. cap.13, p.355-372.

STRICKLAND, S. G.; NICHOL, J. W.; McCALL, C. M. STUART, D. A. Effect of carbohydrate source on alfafa somatic embryogenesis. Plant Science, v.48, p.113121, 1987.

SWINGLE, W. T.; REECE, P. C. The Botany of citrus and its wild relatives. In: REUTHER, W.; WEBBER, H. J.; BATCHELOR (Ed.) The citrus industry. Berkeley: University of California Press, 1967. p.190-430. 
TEÓFILO SOBRINHO, J.; POMPEU JUNIOR, J.; FIGUEIREDO, J. O.; JACON, J. R. Porta-enxertos para laranjeira 'Pera', clone premunizado - Resultado de 10 anos de produção. Laranja, v.10, n.2, p.269-279, 1989.

TEÓFILO SOBRINHO, J.; ROESSING, C.; RODRIGUEZ, O.; POMPEU JUNIOR, J. Estudo preliminar de produção de tangerinas 'Cravo' e 'Ponkan' em nove portaenxertos. Ciência e Cultura, v.21, n.2, p.392, 1969a.

TEÓFILO SOBRINHO, J.; ROESSING, C.; RODRIGUEZ, O.; POMPEU JUNIOR, J. Tendência de produção de laranjeiras 'Valência' e 'Natal' em nove porta-enxertos. Ciência e Cultura, v.21, n.2, p.391-392, 1969 b.

TEÓFILO SOBRINHO, J.; POMPEU JUNIOR., J.; FIGUEIREDO, J. O.; JACON, J. R.; BARBIN, D.; DEMÉTRIO, C. G. B. Porta-enxertos para laranja 'Pera' Citrus sinensis L. Osbeck. In: CONGRESSO BRASILEIRO DE FRUTICULTURA, 8., Brasília, 1986. Anais. Brasília: Sociedade Brasileira de Fruticultura, 1986. p.117-121.

VARDI, A. Protoplast derived from different citrus species and cultivars. Proceedings of the International Society of Citriculture, v. 1, p.149-152, 1981.

VARDI, A.; GALUN, E. Recent advances in protoplast culture of horticultural crops: Citrus. Scientia Horticulturae, v.37, p.217-230, 1988.

-VARDI, A.; GALUN, E. Isolation and culture of citrus protoplasts. In: BAJAJ, Y. P. S., (Ed.) Plant protoplasts and genetic engeneering I. Berlin: Springer-Verlag, 1989. cap.2.3, p.147-159. (Biotechnology in Agriculture and Forestry, 8 ).

VARDI, A.; SPIEGEL-ROY, P. Plant regeneration from Citrus protoplasts: Variability in methodological requirements among cultivars and species. Theoretical and Applied Genetics, v.62, p.171-176, 1982. 
VARDI, A.; BLEICHMAN, S.; AVIV, D. Genetic transformation of Citrus protoplasts and regeneration of transgenic plants. Plant Science, v.69, p.199-206, 1990.

VARDI, A.; HUTCHISON, D. J.; GALUN, E. A protoplast-to-tree syatem in Microcitrus based on protoplasts derived from a sustained embryogenic callus. Plant Cell Reports, v.5, p.412-414, 1986.

VARDI, A.; SPIEGEL-ROY, P.; GALUN, E. Citrus cell culture: isolation of protoplasts, plating densities, effect of mutagens and regeneration of embryos. Plant Science Letters, v.4, p.231-236, 1974.

VASCONCELIOS, P. W. C. Estudo comparativo da laranjeira "Bahia comum", sobre cinco diferentes porta-enxertos. Boletim de Agricultura, v.40, p.587-621, 1939.

VIEIRA, M. L. C. Estudo citotaxonômico de espécies brasileiras do gênero Stylosanthes Sw. Piracicaba, 1988. 135p. Tese (Doutorado) - Escola Superior de Agricultura "Luiz de Queiroz", Universidade de São Paulo.

YAMAMOTO, M.; KOBAYASHI, S. A cybrid plant produced by eletrofusion between Citrus unshiu (satsuma mandarin) and C. sinensis (sweet orange). Plant Tissue Culture Letters, v.12, n.2, 131-137, 1995.

YAO, J.-L.; WU, J.-H.; GLEAVE, A. P.; MORRIS, B. A. M. Transformation of citrus embryogenic cells using particle bombardment and production of transgenic embryos. Plant Science, v.113, p. 175-183, 1996. 